\title{
Envy of the rich is one reason that Americans favor reducing income inequality
}

Authors: MDR Evans (University of Nevada) and Jonathan Kelley (University of

Nevada and International Survey Center)

Please cite as:

Evans, MDR and Jonathan Kelley. 2019 "Envy stimulates opposition to income inequality: Envy, self-interest, party politics and inequality attitudes in the US." American Sociological Association Annual Meeting. Section on Social Psychology Refereed Roundtables. Tuesday, August 13, 2:30 to 4:10pm, Sheraton New York, Third Floor, Riverside Ballroom

Key words:

social norms; redistribution; moral norms; inequality; equity and efficiency; equality; ideology; interests; political parties; social cohesion; stratification

\section{Abstract}

Research question: Why do some Americans evaluate income inequality as too high whereas others do not? Does envy of the rich (the desire to "chop the top"), matter to these evaluations, even above and beyond other well-known influences? We explore this issue by extending a standard model of social-structural and political influences on inequality aversion/ desire to reduce income inequality to include self-reported income envy (and including perceived self-interest as a control variable). Key findings: (1) Envy of the rich has a moderately strong relationship with seeing the current income distribution as too unequal: The total effect of envy on inequality aversion is positive and moderately strong. (2) This effect persists unchanged after taking family political and stratification background, demographics, and current social class/stratification position into account. (3) It persists when we also control perceived economic selfinterest in inequality reduction. (4) Part of the effect is indirect through political party preference, but the direct effect of envy remains moderately important even when party 
is taken into account (5) The effect is strong among Republicans, but absent among Democrats. Data and methods: Data are from the International Social Science Survey Round 20, USA 2016-2017, a representative US national sample ( $\mathrm{N}=1,778$ in the main wave and 2496 in two developmental waves). Methods include descriptive statistics; CFA for scale construction; OLS and multilevel regression analysis; and SEM to check causal issues. Theoretical implications: Attitude towards income inequality, also called inequality aversion or norm on income inequality, is the offspring of many parents; envy is one of the generative influences, in addition to structural and political roots of public opinion and policy-relevant attitudes. Support for redistribution, therefore, encompasses not only a desire for social cohesion through mechanical solidarity based on equality of condition, not only a self-interested desire to reap some of the redistributed riches, not only a fixed political commitment to this goal, but also an envy component, specifically among people on the right of politics.

\section{Introduction: Why study attitudes towards income inequality}

Do the "tall poppies, the "1\%", have too much? Does public opinion hold that income inequality should be reduced? America has the most unequal income distribution of any advanced country, but is this good or bad? Who is averse to current levels of income inequality and who supports them? Existing social structural models of influences on attitudes towards income inequality provide a good foundation, but a woefully incomplete explanatory edifice of the moral economy of income inequality. A myriad influences shape Americans' evaluations of current income inequality as good or bad or somewhere in between, and hence the strength of their motivation for supporting or opposing downwards income compression - this paper focuses on one in particular: envy. The role of envy of the rich in shaping the general public's attitudes towards income inequality has been neglected in prior research, but we will show that it is one of the forces shaping evaluations of inequality, and far from the least of them. 


\section{Theory, prior research, and hypotheses}

Income inequality and redistribution form an ongoing focus of discussion and debate throughout the advanced societies. Prior international and US research has identified a number of social structural influences on these attitudes, yet the explanatory power of these models is low, with most R-squareds under $10 \%$ even in models that include a compelling array of structural predictors. Accordingly, it is time to broaden the focus of research to encompass a wider array of influences. Following recent trends in political sociology (Feinstein 2020), we argue that emotion should be incorporated into existing models, in our case, models of inequality attitudes, and we begin this expansion by examining the role of envy. As detailed below, some writers distinguish "malicious" and "benign" envy; this paper focuses on the role of "malicious income envy" which we can define as wanting to take away income from those who are felt to have too much. ${ }^{1}$ Thus, it entails a recognition of income inequality and a desire to "chop the top", even net of any personal gain that redistribution might entrain. This is close to the usage of "envy" in ordinary language in the general population, as will be seen below. It is logically possible that members of the general public might perceive excessive income inequality but not want to address that through redistribution, however, as we will see below, mounting evidence shows that these elements are born of one whole - inequality aversion - in the public mind. We do not claim that envy is the only relevant emotion driving attitudes towards income inequality, but rather we take the position that exploring the role of emotions in shaping attitudes toward income inequality is best served by extending the baseline structural models to include specific emotions, assessing the impact of each and ultimately combining the fruits of that research into a general model. We return to the issue of the general model in the Discussion.

The approach to theory taken here is a combination of deduction - hypotheses derived from prior research and theory -- and induction (also called "grounded theory") exploration of data with a goal of theory building. We propose a series of models incorporating structural and political socialization and contemporaneous influences and

\footnotetext{
1 "Benign envy" is usually defined as something close to what sociologists would recognize as the Hope Factor (Zagorski 1994), emulation, anticipatory socialization, role modelling. It warrants future attention, but is not the focus of this article.
} 
augment them with envy. This much is deductive work. But exploration after the main analysis revealed an important serendipitous finding (Merton and Barber 2004), an interaction between envy and political party affiliation, which we will foreshadow and interpret in this section on theory and hypotheses, but which will, in the future, need to be replicated in other research where it will be an a priori hypothesis.

\section{Theory and prior research on attitudes towards inequality}

Imagine a landscape: winds, rain, waves, animals, people, the deep motions of the earth, and cosmic events all intentionally or unintentionally shape it. Similarly, many influences shape public opinion in general (Pettigrew and Hewstone 2017 ) and, more specifically shape the moral economy of income inequality - attitudes and values about the legitimate amount of income inequality and about whether redistribution is warranted or desirable (Evans and Kelley 2018a, Hadler 2005, Sachweh 2012). Here, we focus on one such influence, income envy, and on one aspect of inequality attitudes, specifically on the evaluation of the degree to which current income inequality departs from ideal, which we will, for brevity, refer to as inequality aversion.

Attitudes towards income inequality, also called inequality aversion

The general public's evaluation of income inequality is of theoretical importance because it is at the intersection of concern with, on the one hand, agency and equity in the distribution of reward and, on the other hand, the importance of equality as generating mechanical solidarity through similarity of condition and thence social cohesion. This is a locus of potential collision between two competing claims to reward legitimacy that have formed a focus of debate since ancient times. On the one hand, equity theory posits that understandings of justice in the general population hold that incomes should be unequal as income is the appropriate reward to agency and competence at work (Alwin 1992, Aristotle 350 BCE, Ritzman and Tomaskovic-Devey 1992, Roex, Huijts and Sieben 2019) versus equality where income is a resource for mechanical solidarity, communion, and societal membership (Durkheim 1961 [1893], Eriksson 2018, Jasso and Rossi 1977, Jasso 1980). As with justice issues more generally, the process of forming evaluations of the justice of an income distribution will involve complex balances of general principle, conformity to the schemas and judgments of legitimated authorities, perceived self-interest, interests of valued others including 
reference groups, evaluations of the justice of the income determination processes, assessments of the contributions and claims of different parties, and possibly other elements (Jasso 2015). This theoretical centrality to the discipline has stimulated a lively tradition of research concerning the connection of social structural and socialization forces at the individual and national levels to individuals' inequality aversion (Castillo 2011, Evans and Kelley 2018a, Fernandez and Jaime-Castillo 2018, Hadler 2005, Heiserman and Simpson 2017, Ignacz 2018, Kelly and Enns 2010, Kolczynska and Merry 2016, Rodriguez-Bailon et al. 2017, Roex, Huijts and Sieben 2019, Smith and Mateju 2012, Steele 2015). Yet the evidence to date is that this approach explains little of the diversity in inequality aversion.

In addition, attitudes toward income inequality of interest sociologically because they are potentially a source of action. In general, theory holds that our evaluations of whether situations, characteristics, behaviors, etc are good or bad affect our intentions to take action - collective or individual - about them (e.g. Bandura 2018, Fishbein and Ajzen 2010). Hence our evaluations of whether income inequality is too low or too high are likely to affect our policy preferences and political behavior (Arsenio 2018, Fernandez and Jaime-Castillo 2018, Heuer, Mau and Zimmermann 2018, Ven and Zeelenberg 2019), so understanding the sources of our inequality evaluations can have broader implications (Brooks and Brady 1999, Manza and Brooks 2012), for example via the comparison, status, and power dimensions of Jasso's unified theory (Jasso 2008).

Public opinion evaluating the current distribution of income is also of practical importance because reduction of income inequality - whether by enhancement of the capacities of the disadvantaged or by tax and transfer (redistribution) programs or by other means -- forms the focus of a great deal of governments' activities, even in countries with relatively limited welfare states, such as the United States (Beramendi and Rehm 2016, Heuer, Mau and Zimmermann 2018), although some approaches are much more successful than others (Beramendi and Rehm 2016, Brady and Bostic 2015) and some government actions in this domain have unintended consequences (Breznau and Hommerich 2019, Evans and Kelley 2018a). Evaluations of income inequality are of both theoretical and practical importance because some evidence suggests that public opinion on inequality may shape governmental policy and institutional arrangements (Jo and Choi 2019, Kelly and Enns 2010, Weakliem, Andersen and Heath 2005), 
although there is also evidence for causality in the other direction (see the thorough reviews of this literature in Breznau 2017, Mettler and Sorelle 2014), and evidence in some domains for a citizen-government disconnect (Mettler 2018).

\section{Income envy}

Recent experimental research and theorizing in social psychology suggests that in addition to the influences previously established in the sociological and political science literatures on sources of evaluations of societal income inequality and inequality aversion/ support for inequality reduction, income envy may also play a distinct role (Foy et al. 2014, Hegtvedt and Parris 2014, Jasso 2007, Sznycer et al. 2017, Turner 2007). Laboratory experiments suggest that part of the mix of motivations for viewing resource inequality negatively and for supporting compression of the income distribution may be "levelling down" or "cutting down the tall poppies"-- taking from the rich for its own sake -- rather than the Robin Hood approach which emphasizes taking from the rich in order to give to the poor (Kemp and Bolle 2013, Sznycer et al. 2017). The desire for someone else not to have the good (in this case the high income) is one long established meaning of "envy" (Aristotle 350 BCE , D'Arms 2017, Laertius 240BCE [1925], Schoeck 1987[1966], Turner 2007). As one writer put it, "...envy is grief over someone else's good fortunes..." (Laertius 240BCE [1925]) and the pithy Scythian, one of the 7 sages of ancient Greece, when asked why envy always bring pain, is reputed to have said, "...because not only do their own evils bite them, but the good fortunes of others pain them too". Some psychologists refer to this as "malicious envy"2, but for simplicity, and following the general sociological usage, we will simply refer to it as "envy." In this meaning, income envy is an emotion (D'Arms 2017, Feather 1999, Hegtvedt and Parris 2014), with no requirement that it be a personality disposition across other domains such as love or beauty (Kemp and Bolle 2013, Schoeck 1987[1966], Smith et al. 1999, Turner 2007). Income envy is closely related to the concept of "ressentiment" which early theorists saw as the determinant of inequality attitudes (Kierkegaard 1846, Nietsche 1887 [1967], Scheler 1914 [1994]), but we would argue that

\footnotetext{
${ }^{2}$ In this terminology an upward social comparison that sparks a desire to rise to the other's higher level rather than to cut down the other to one's own level is called "benign envy" (see the thorough review of the psychological tradition in van de Ven and Zeelenberg 2019). Sociologists would be likely to refer to this phenomenon as role modeling or emulation or the "hope factor" effect (e.g. Zagorski 1994 and the literature following from that). By contrast, we are concerned here with the envy in which the social comparison stimulates a desire to reduce the prosperity of "the rich".
} 
it can operate alongside other motivations, such as conceptions of justice and social structural influences, rather than dominating them. The moral economy of income inequality clearly has multiple dimensions, with attitudes and values about the process (status attainment and earnings) especially emphasizing equity (Evans, Kelley and Peoples 2010) and opportunity. By contrast, attitudes and values about outcomes (income distribution, income inequality) mix equity goals, solidarity/ cohesion motivations, and "package deals" accepting policies linked to legitimated institutions or core cultural elements (Breznau and Hommerich 2019, Kelley and Zagorski 2005, Koos and Sachweh 2017, Sachweh 2012). This paper focuses on the latter, on attitudes about outcomes.

For present purposes, we focus on the net impact of envy of the rich, separate from selfinterest in gain, separate from desire to make morally good use of income that might be "harvested" from the top of the income distribution, and separate from positive feelings about the poor. These other matters are also likely to play their own roles in attitudes towards inequality, but they do not form the focus of this analysis. Note that the question is not whether envy is the only, or even the primary, motivation for evaluating inequality as too high, but rather to discover whether envy plays a distinct role in generating inequality aversion and to assess how large that is.

Our aim is not to make a moral judgement about whether envy is a good thing or a bad thing (unlike de la Mora 2000, Rawls 1971). Instead, it is to examine the influence that income envy exerts on income inequality aversion.

The results from the laboratory experiments noted above demonstrate that envy is a source of egalitarian preferences in a situation isolated from daily life and hence having no real enduring consequences. By contrast, the "real world" attitudes on income inequality of interest in this investigation entrain many cultural, subcultural, and personal understandings of how inequality arises, as well as group affiliations in politics that entail attitude conformity. Enduring influences of socialization can also continue to shape inequality attitudes in later life in "real world". Hence, we are safer treating the experiments as providing working hypotheses rather than providing results that translate directly to the "real world situation". Thus, the experimental results imply 
the hypothesis that, in the general population, in addition to previous known determinants, income envy, should influence inequality aversion.

Our analyses here are complementary to this prior work by extending the scope of potential confounding variables and hence more closely approaching causal measurement (Morgan and Winship 2014). We argue that income envy affects inequality aversion net of the contemporaneous and socialization-generated influences of social structural location and political party adherence influences already known to matter. Of course, there are many influences on these evaluations, so assessing envy's role will require as many potentially confounding influences as possible to be controlled.

\section{Contextual influences}

This article focuses on the US, but results could be different elsewhere. A flourishing tradition of research has established that societal differences in public opinion on income inequality are large (Austen 2002, Evans and Kelley 2007, Gijsberts 2002, Hadler 2005, Kelley and Evans 1993, Kelley and Evans 1995, Kolczynska and Merry 2016, Larsen 2016, Mason 1995, McCall 2003, Papadakis and Bean 1993, Roex, Huijts and Sieben 2018, Simkus and Robert 1995, Zagorski 1999).

Cultural differences between English-speaking nations (10 points out of 100 more tolerant of income inequality), formerly Communist nations (9 points out of 100 less tolerant of inequality), and other nations are large (see the multi-level model reported in Appendix B). In particular, Americans are more tolerant of inequality than are people in peer countries, especially outside the Anglo-Celtic culture group (Austen 2002, Hadler 2005, Kelley and Evans 1993, Kelley and Evans 2009, Osberg and Smeeding 2006, Roex, Huijts and Sieben 2018). This could potentially reflect its English language and institutional heritage (Beramendi and Rehm 2016, Castles 2010, Kelley and Evans 1993, Osberg and Smeeding 2006, Zagorski 1996), its objectively high income inequality (Osberg and Smeeding 2006), its progressive net tax-and-transfer system (Beramendi and Rehm 2016), and/or its perceived high levels of social mobility (Day and Fiske 2016, Kelley and Kelley 2009, Steele 2015), and/or its cultural individualism (Hofstede 1984, Inglehart 2008). In addition, the possibility that greater inequality

elicits perceptions of top earners as especially meritorious (Feather 1999, Heiserman and 
Simpson 2017), might make Americans less envious than in peer societies. For present purposes, the reason to take note of the broader context is two-fold: (1) The prior research suggests that both the levels of actual inequality and the tolerance of it are greater in the US, but that (2) the relationships among variables are very similar. This similarity suggests that it is reasonable to tentatively generalize the results on the relationships among variables discovered in this investigation to a broader range of countries, at least as working hypotheses.

\section{Partisanship}

From a slightly different angle, an approach that captures some of the nuances of chains of moral reasoning that generate these attitudes holds that deep-seated values of agency and community/ communion - separate dimensions, not opposite ends of one dimension (Bandura 2018) - have become deeply embedded in political party identification and loyalties. Specifically, people who strongly value agency tilt towards the Republicans (and away from the Democrats) while people who strongly value membership and community/ communion tilt towards the Democrats (Eriksson 2018). For our purposes, the key implication is that net of other influences, political party identification will impact income inequality evaluations, either as a causal effect, as a proxy for the underlying values, or as a featuring structuring networks of beliefs (Boutyline and Vaisey 2017, Brader and Tucker 2018, Gerber, Huber and Washington 2010, Mullinix 2016). This could be associated with parents' partisanship (Alwin and Krosnick 1993, Jennings, Stoker and Bowers 2009, Niemi and Jennings 1991), too. Hence, both parents' party and respondent's current party affiliation ought to be controlled in order to avoid confounding variables/ omitted variables bias.

\section{Self-interest}

Decades of research on attitudes towards earnings and income inequality have diligently sought self-interest effects as represented by impacts of socioeconomic position, but found rather weak effects (Austen 1999, Crepaz 2016, Galland, Lemel and Frénod 2013, Gijsberts 2002, Hadler 2005, Kelley and Evans 1993, Kelley and Evans 2009, Kocer and Werfhorst 2012, Kulin and Svallfors 2013, Linos and West 2003, Shamon and Duelmer 2014, Smith and Mateju 2012), although there is support in experimental research, at least when the source of the inequality is not specified (Sznycer et al. 2017). The many variables that have been explored under the rubric of 
self-interest include education, occupational status, income, and the like, sometimes called "pocketbook" or "hip pocket" effects (ably summarized in Owens and Pedulla 2014 and in Fernandez and Jaime-Castillo 2018). Research extending and revising this line of reasoning to incorporate insights from the group dynamics and reference group literatures finds that reference group composition and definition modify the effects of short-term atomistic economic self- interest on inequality attitudes (Breznau and Eger 2016, Evans and Kelley 2017, Kelley and Evans 1995).

The relative weakness of these effects has been dubbed the government-citizen disconnect (Mettler 2018). While we acknowledge the importance of self-interest, we argue that even aside from any personal gains or losses from inequality compression any short-term economic self-interest - envy will have an independent impact: The more you envy the rich, the more you will favor income inequality reduction/compression, even aside from whether you stand to gain or lose by it. Economic self-interest is an important control variable and including it puts to rest concerns that income envy might proxy for it (thereby artificially inflating envy's effects).

\section{Perceived self-interest}

We suggest that it is too early to dismiss atomistic economic self-interest as an influence on inequality attitudes. This is not easy to do because the indicators commonly used do not explicitly measure perceived self-interest in a more equal income distribution, i.e. the degree to which one would expect to gain or lose from inequality reduction/ compression (Sznycer et al. 2017). It is conceptually important to distinguish anticipated personal gain, on the one hand, from actual income, and from income envy (the negative emotion associated with other people's high incomes).

To measure this empirically, we have developed a new subjective measure of economic self-interest in income inequality reduction (identifying reference suppressed for review). It essentially asks whether you think you would gain from it; details are given in the measurement section.

Accordingly, we will include not only the usual indicators, but also our novel direct measure of perceived economic self-interest in inequality reduction - the extent to 
which respondent perceives that they would gain or lose from reducing income inequality.

Primary socialization, demographic, and current stratification position influences

Potential stratification effects on attitudes towards income inequality are, of course, not limited to self-interest, but could also reflect subcultural differences and influences of social position and reference groups on societal perceptions. Prior research (Austen 1999, Centola 2015, Evans and Kelley 2018b, Galland, Lemel and Frénod 2013, Gijsberts 2002, Hadler 2005, Kelley and Evans 1993, Kelley and Evans 2009, Kocer and Werfhorst 2012, Kolczynska and Merry 2016, Kulin and Svallfors 2013, Shamon and Duelmer 2014, Smith and Mateju 2012), directs our attention (1) to primary socialization influences especially including parents' education, parents' occupation, respondent's current perception of parents' social hierarchical position while respondent was growing up, and religiosity in the family of origin; (2) demographic influence of age and gender; and (3) current stratification influences of respondent's own education, own occupation, and family income. (Of course, parents' party and respondent's current party are important also, as described in the section on "partisanship" above.) For present purposes, these are control variables, important to include so that effects properly attributed to them are not proxied by income envy.

\section{Hypothesis}

H1: The more income envy a person feels, the more they will evaluate their society's income inequality as too large, ceteris paribus.

Otherwise put, the stronger the envy, the more negative the evaluation of societal income inequality, other things being equal. The greater the envy, the greater the inequality aversion, net of other influences. The other things we are able to assess are those discussed above and listed in Eq. 1. They include political, stratification and religious socialization experiences; demographic factors; perceived self-interest; and current social stratification position. 
Besides the a priori guidance and hypothesis building detailed above, we also engaged in serendipity and exploratory analysis (Locke 2007, Merton and Barber 2004), specifically about whether the effects of income envy differ by political party adherence. Envy is not an emotion our society admires, possibly even regards as somewhat disgusting. We investigated this interaction (rather than the infinite array of other possibilities) because opposition to income inequality is a cornerstone of the left, and hence is seemed plausible that inequality aversion would be very widespread among Democrats, envious or otherwise, but Republicans are more supportive of income inequality (for reasons discussed above), so it seemed likely that income inequality aversion among Republicans might stem from a "dirty little secret", malicious income which they feel to be illegitimate, but which shapes their attitudes anyway. In short, the possibility that the workings of envy might depend on groups affiliations and group culture. In the event, we found a large and strong interaction such that, net of other influences, the "inequality aversion gap" between the least envious Democrats and Republicans amounts to 40 points out of 100 - a yawning gulf - but envy strongly increases support for inequality reduction among Republicans (leaving it unchanged among Democrats), so that the most envious Republicans are only about 20 points out of 100 below their highly envious Democrat peers in support for redistribution. Because this is an exploratory finding, theorizing about it and proposing a working hypothesis from it are matters for the Discussion and they are taken up there.

\section{Data, Measurement and Method}

\section{Data}

Data are from the International Social Science Survey Round 20, USA 2016-2019. The main wave (January 2019) is a representative US national sample $(\mathrm{N}=1,778)$ from Survey Sampling International's well-regarded internet panel (SSI; www.surveysampling.com). The questionnaire is self-completion, so for each question, all the answers are simultaneously visible to the respondent. We requested only computer and tablet users, but some cell phone users slipped through which is a problem for some complex batteries of questions; fortunately, none is needed for the present analyses. 
There were also two developmental waves ( $N=1,323$ in 2016 and $N=1,173$ in 2017), both Amazon 'Mechanical Turk' internet-based samples, also US wide. These are swift, convenient, and cost effective. Surprisingly Mechanical Turk sampling has proven to be remarkably accurate for multivariate analyses (Clifford, Jewell and Waggoner 2015, Springer et al. 2016, Weinberg, Freese and McElhattan 2014), although for estimation of population means these samples may need to be weighted because they over represent younger and highly educated people (not an issue for the present analysis). For multivariate analyses of issues central to this paper regarding family background, SES, and inequality we have found that they are virtually equivalent to the main wave (see Table 3, last few rows; further details available on request). To achieve more statistical power from the larger sample size, we have therefore pooled the developmental waves with the main sample, and include "wave" measured as dichotomous variables in relevant analyses.

\section{Measurement}

\section{Income Envy (focal predictor/ independent variable)}

We are specifically interested in envy associated with income inequality, so we developed a new domain-specific scale focusing on envy of the rich (for the moment bracketing the issue of envy-as-personality vs envy-as-subculture), rather than relying on the generalized "dispositional envy" scale focused on envy as a personality trait that is generalized across domains such as income, beauty, and talent (Smith et al. 1999, Sznycer et al. 2017).

The envy questions verbatim: 


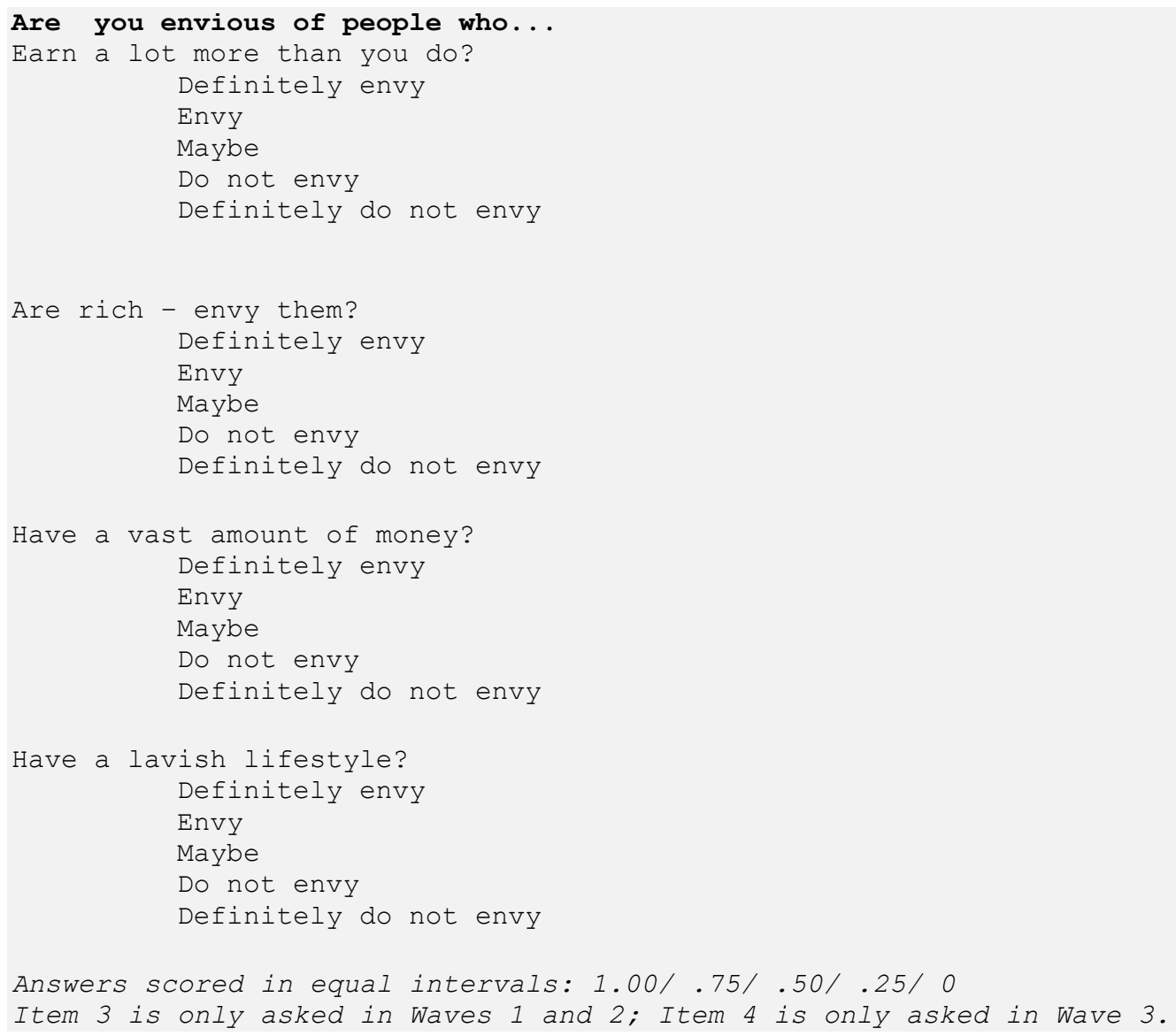

Answers are scored in equal intervals from a low of zero ("Definitely do not envy") to a high of 1 ("Definitely envy"). The correlations among the 3 candidate items are all high (over 0.8) in the pooled file, and the standardized CFA loadings are all over 0.9, indicating that they are all indicators of the same dimension/ concept (Table 1, Panel A). Moreover, all three items have very similar correlations with criterion variables (Table 1, Panel B), a feature that is a key element of the classic measurement model (Bollen 1989, Treiman 2009). For example, all are near -0.2 with age and all are near 0 with education.

(Table 1 about here) 
Table 1. Measurement of envy. Correlations, means and standard deviations. International Social Science Survey Round 20, USA 20162019.

\begin{tabular}{ccc}
$\begin{array}{c}\text { Items in the scale } \\
\text { (Alpha=.94) }\end{array}$ & & $\begin{array}{c}\text { CFA factor } \\
\text { loadings }\end{array}$ \\
\hline (1) & $(2)$ & (3)
\end{tabular}

\section{Panel A: Inter-item correlations}

$\begin{array}{lcccc}\text { (1) Earn a lot more than you do } & 1.00 & & & .91 \\ \text { (2) Are rich } & .87 & 1.00 & & .95 \\ \text { (3) Vast money/ lavish standard living } & .83 & .87 & 1.00 & .91\end{array}$

Panel B: Criterion variables

\begin{tabular}{|c|c|c|c|c|}
\hline Age & -.04 & -.03 & -.04 & \\
\hline Male & .00 & .00 & .00 & \\
\hline Churchgoing & -.05 & -.07 & -.07 & \\
\hline Education & .07 & .04 & .04 & \\
\hline Occupational status & .05 & .02 & .02 & \\
\hline Family income (In) & -.02 & -.02 & -.02 & \\
\hline Democratic Party & .08 & .08 & .07 & \\
\hline For a more equal income distribution & .26 & .23 & .23 & \\
\hline \multicolumn{5}{|l|}{ Panel C: Descriptive statistics } \\
\hline Mean (points, 0 through 1 ) & 0.46 & 0.46 & 0.46 & \\
\hline Standard deviation & 0.30 & 0.30 & 0.31 & \\
\hline Number of cases & 4,264 & 4,259 & 4,250 & 3,289 \\
\hline
\end{tabular}

These results justify treating the "lavish lifestyles" and "vast amount of money" items as functional equivalents. In turn, that justifies pooling the waves and building an "income envy" scale using all the envy items. Our models will retain a "Wave" indicator to control for unmeasured differences.

Levels of income envy are widely dispersed, with a standard deviation around 0.3 on a scale of 0 to 1 , and, on average, are neither particularly high nor particularly low. The means are very close to the middle, around "Maybe" (Table 1, Panel D). Thus, although people might not be proud to be envious, there is little sign of social desirability bias. 
Inequality aversion/ attitudes on income inequality (Response/ dependent variable)

Inequality aversion/ attitude towards income inequality is measured with a five-item scale originating in two items used in the 1987 ISSP Social Inequality module and extended subsequently in the International Survey of Economic Attitudes (Kelley et al. 1998a). The two-item version of this scale has been widely used in dozens of international surveys such as the ISSP and WVS, most recently in 30 never-Communist nations with $\mathrm{N}=62,180$. Reliability of the two-item scale is .70 in the pooled sample and approximately that in each nation separately (Evans and Kelley 2018a). Appendix A gives details. These are now standard questions for international comparative surveys, with one or more used in many surveys and dozens of nations since the 1980s. These include the International Social Survey Programme's Inequality and Role of Government modules, the US General Social Survey, the German Internet Panel (Naumann 2018), the British Social Attitudes Survey, and the European Social Survey, among many others. They have been used successfully in prior research (e.g. Breznau 2010, Fernandez and Jaime-Castillo 2018, Jaeger 2009, Kenworthy and McCall 2008, Sikora 2005, Zagorski 1999).

The items ${ }^{3}$ :

\footnotetext{
3 : Answer categories were "Strongly agree" (scored 1.0), "Agree" (scored .75), "Neither agree nor disagree" (.50), "Disagree" (.25), and "Strongly disagree" (0). Other equal interval scoring choices (for example, 1 to 5 in traditional Likert-style) would be mathematically identical, leading to exactly the same results except for a change of scale. We use the 0 to 1 or 0 to 100 ranges because metric regression coefficients in them are more readily interpretable.
} 


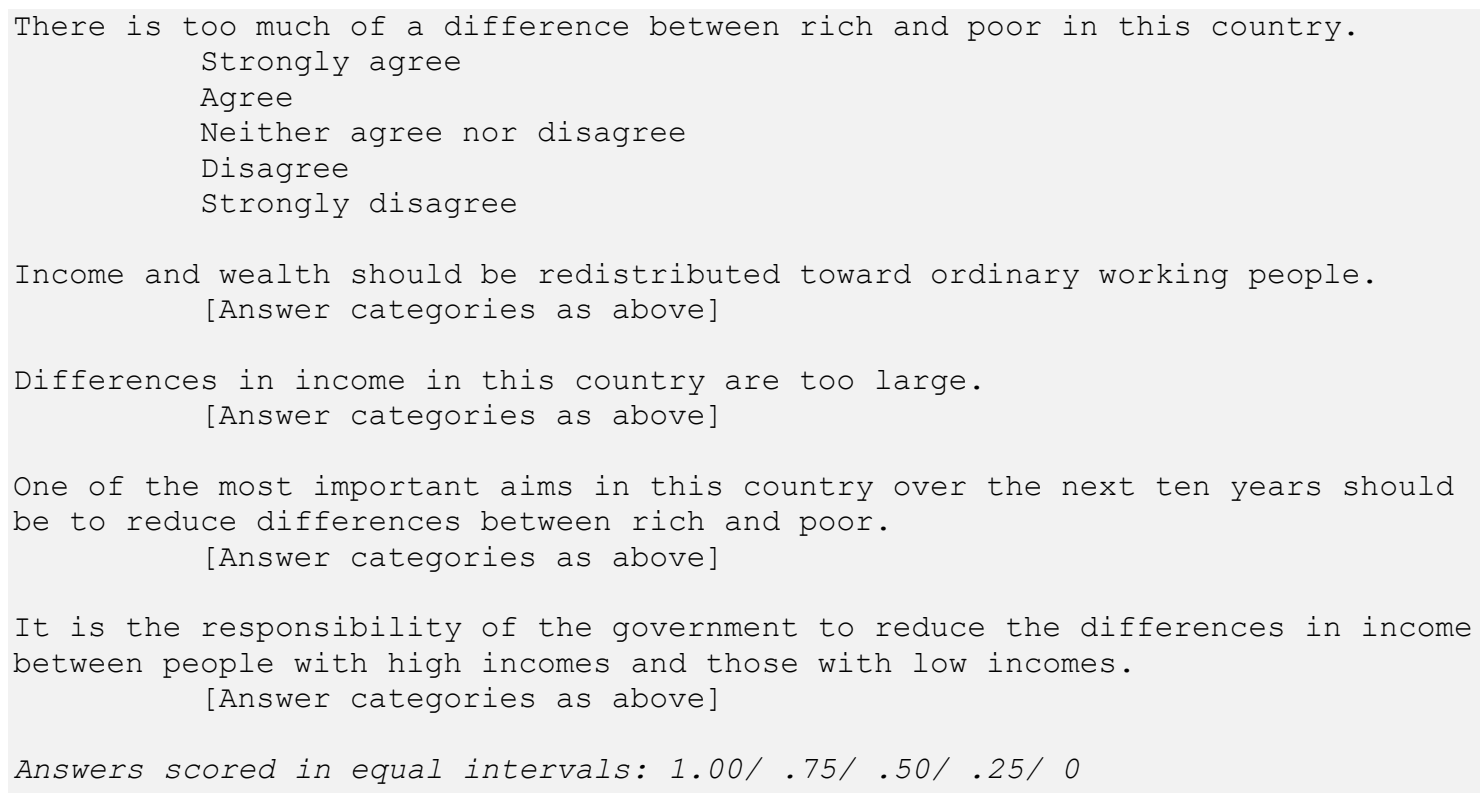

\section{Measurement properties}

Thus, the American general public has well defined income inequality aversion/ attitudes towards income inequality. Measurement properties are good with high interitem correlations and CFA loadings (Table 2, Panel A) and correlations with criterion variables (Panel B) showing the consistent pattern expected for items measuring a single concept in the classical measurement model (Bollen 1989, Treiman 2009). The education and income correlations are similar to those found in previous research on the EU-15 and all OECD countries using a different 3-item scale of income inequality aversion/ attitudes towards income redistribution (Linos and West 2003), suggesting that our findings may well generalize to other advanced societies. Further details supporting this view are in Appendix A.

[Table 2 about here] 
Table 2. Attitudes toward income inequality (also called redistribution attitudes and inequality aversion): Measurement. Correlations, confirmatory factor loadings, and descriptive statistics. USA 2016-2017.

\begin{tabular}{lccccccc}
\hline & \multicolumn{3}{c}{ Items in the scale (Alpha=.92) } & $\begin{array}{c}\text { CFA } \\
\text { factor }\end{array}$ \\
\cline { 2 - 6 } & $(1)$ & $(2)$ & $(3)$ & $(4)$ & (5) & loadings \\
\hline Panel A: Inter-item correlations & & & & & & \\
(1) Differences too large & 1.00 & & & & & 0.84 \\
(2) Differences between rich and poor & 0.82 & 1.00 & & & & 0.81 \\
(3) Government responsibility to reduce & 0.63 & 0.60 & 1.00 & & & 0.82 \\
(4) Aims for country: reduce differences & 0.73 & 0.69 & 0.75 & 1.00 & & 0.88 \\
(5) Redistribute income and wealth & 0.67 & 0.65 & 0.75 & 0.74 & 1.00 & 0.84
\end{tabular}

\section{Panel B: Criterion variables}

\begin{tabular}{|c|c|c|c|c|c|c|}
\hline Envy (3-item scale) & 0.21 & 0.21 & 0.24 & 0.22 & 0.23 & \\
\hline Age & -0.02 & -0.02 & -0.01 & 0.01 & 0.00 & \\
\hline Male & -0.06 & -0.06 & -0.02 & -0.02 & -0.05 & \\
\hline Churchgoing & -0.09 & -0.07 & -0.05 & -0.07 & -0.07 & \\
\hline Parents' political party & 0.14 & 0.14 & 0.16 & 0.15 & 0.15 & \\
\hline Education & 0.02 & -0.01 & 0.01 & 0.00 & -0.04 & \\
\hline Occupational status & -0.03 & -0.03 & -0.01 & -0.03 & -0.06 & \\
\hline Family income (In) & -0.13 & -0.14 & -0.15 & -0.14 & -0.15 & \\
\hline Expects personal gain from equality & 0.32 & 0.33 & 0.36 & 0.35 & 0.35 & \\
\hline Democratic Party & 0.40 & 0.40 & 0.46 & 0.45 & 0.42 & \\
\hline \multicolumn{7}{|l|}{ Panel C: Descriptive statistics } \\
\hline Mean (points, 0 through 100) & 76 & 78 & 56 & 67 & 61 & \\
\hline Standard deviation & 26 & 25 & 34 & 30 & 30 & \\
\hline Number of cases & 4,254 & 4,272 & 4,271 & 4,265 & 4,260 & 3,365 \\
\hline
\end{tabular}

The means (Panel C) show a clear perception that income differences are too large (first two items, means near "Agree") and somewhat less agreement about reducing them (items 3, 4, and 5, means about half-way between "Neither agree nor disagree" and "Agree"). Research with the full five-item scale in the International Survey of Economic Attitudes gives essentially identical measurement results (identifying reference 2018 suppressed).

In short, public evaluations of income inequality are well and reliably measured using these long-established and widely used items. 


\section{A new control variable: Perceived self-interest}

Because this paper focuses on income envy specifically in the sense of "wanting the other not to have a high income" rather than in the sense of "wanting some of the income the other has", it is important to control for self-interest in redistribution (Linos and West 2003). Omitting self-interest could inflate the apparent effect of envy to the degree that they are correlated and that both influence attitudes towards income inequality and redistribution (Morgan and Winship 2014).

\section{Control variables}

Prior research finds effects of some demographic variables, notably age (Lin, Kamo and Slack 2018) and gender (Owens and Pedulla 2014), as well as stratification-related variables that are usually interpreted as indicating self-interest (Kulin and Svallfors 2013, Linos and West 2003), but may also indicate and/ or reference-group interest, perceptual distortion by generalization from social network context, or subcultural framing. The variables include age, gender, attendance at public worship services, education, occupational status, parents' subjective rank, family income, and political party identification. Our measurement is mostly conventional. Appendix $C$ gives details and Appendix D gives correlations among all the variables in the analysis.

\section{Methods}

We take a path-model approach, investigating first the total effect of envy on evaluation of inequality. We then assess the degree to which the apparent envy effect can be explained by family-of-origin characteristics while respondent was growing up (parents' education, parents' occupational status, and parents' attendance at public worship service) and by demographic characteristics (age and sex). At the next stage, we add in parents' political party preference, in case income envy might be part of the package of schemas one learns at the dinner table with one's parents. We then augment this model with respondent's current stratification-related characteristics - features that 
could structure their short-term economic self-interest and reference groups' interests in relation to compression of the income distribution - their education, occupational status, and current family income. We had originally entered this group in two stages: First, educational and occupational status (since they are important influences on income) and second, income. However, since education and occupational status did not have significant effects either before or after entering family income, for brevity's sake and without loss of information, we only present the model with all three included. Although these variables ought to represent objective self- and reference group interests, prior research points out that objective interest may be less important than perceived interests in shaping evaluation of income inequality (Linos and West 2003, Sznycer et al. 2017). Accordingly, we next augment the model with a measure of subjective self-interest, the degree to which respondent thinks they would gain or lose economically, were incomes to become more equal in the US. Finally, we add current political party preference into the model. (A supplementary SEM model shows that the assumption of causal direction is justified: Party preference affects evaluations of income inequality but there is no reciprocal causation, as detailed in Appendix E).

More formally, we have:

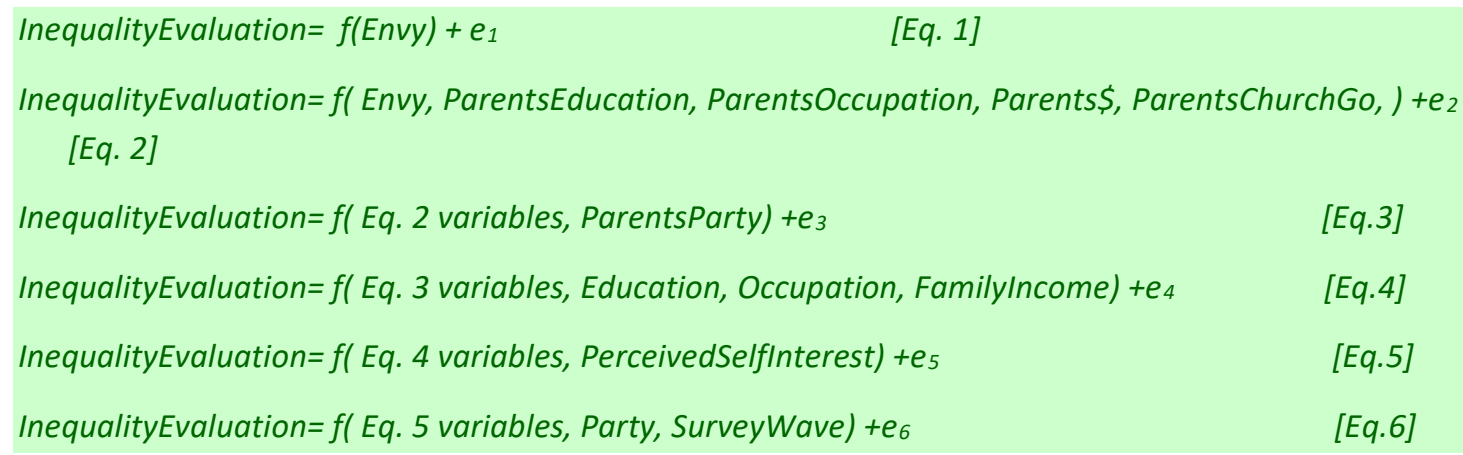

Because there is no geographical clustering and the residuals meet the OLS assumptions, we estimate the models using OLS. Note that in all the models, variance inflation factors for every predictor variable are under 2 , so there is no cause for concern about collinearity (the conservative criterion for concern would be VIF $>5$, a common working standard is that VIF>10 implies collinearity).

We focus on the standardized regression coefficients (sometimes called beta coefficients) that reflect the strength or "tightness" of the relationship between envy and 
income inequality aversion/ attitude towards income inequality net of the other relationships in the model (Sirkin 2006, Treiman 2009, Vittinghoff et al. 2005). Standardized regression coefficients give the change in the dependent variable (in standard deviation units) associated with a one-standard-deviation change in the predictor, net of the influences of the other predictors in the model. As such, they represent the relative influence of all the predictors in the model mapped onto a common scale so that their strength can readily be compared even when they are measured in different units, e.g. years of education and dollars of income. This enables us to compare the strength of the effect of envy on inequality attitudes to the strength of the other predictors. They range between -1.0 (strongest possible negative effect) to 0 (no effect at all) to 1 (strongest possible positive effect). For individual-level variables, a rule of thumb, expressed in absolute values is: $<.05=$ too weak to matter; $0.05-0.09=$ weak, but worth noticing, 0.10-0.19= moderately strong, 0.2-0.3= strong, $>0.3=$ very strong. They can be obtained either by z-scoring the variables and then estimating the regression equation or by transforming the metric regression coefficients (Treiman 2009, Warne 2017). T-statistics and p-values are identical for standardized and metric regression coefficients.

Prior to presenting the analytic results, we will provide some descriptive statistics to set the stage.

\section{Results}

\section{Descriptive results}

Envy is our focal predictor variable. Levels of envy are neither particularly high nor particularly low. The mean is very close to the middle around "Maybe" with very considerable dispersion (Figure 2). Quite a few people have negative feelings about the "tall poppies", but roughly equal numbers are not distressed by the riches of others. Thus, the full spectrum of feelings of envy of the rich (from definitely not to definitely yes) is represented here and the distribution is roughly symmetrical.

[Figure 2 about here] 
Figure 2. Envy (3-item scale): Percent distribution.

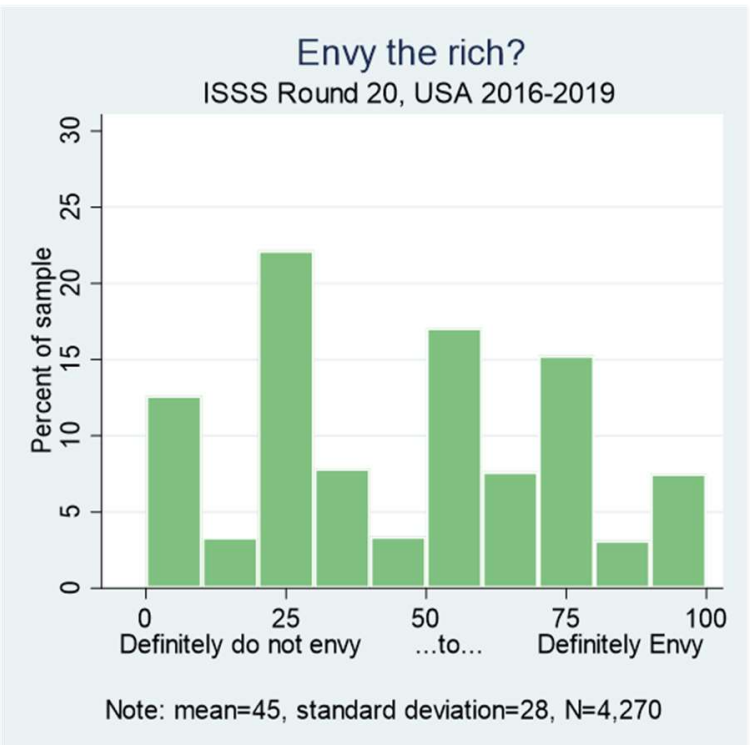

Attitude towards income inequality (also called attitude towards redistribution, also called inequality aversion) is the response/ dependent variable we are setting out to predict. The respondents' evaluations of the US's income distribution are very diverse, with people endorsing opinions across the whole spectrum, but a pronounced tilt towards seeing income inequality as too high and endorsing the view that incomes should be more equal (Figure 3). Recall that the direction of this scale is that perceiving that income inequality as too high/ supporting income equalization/ inequality aversion is scored high. The evaluation of inequality scale has a mean of 69 . This is well above the neutral point of 50 ("Neither agree nor disagree"), not far from mild support (75= "agree" ), but far below strong support (100= "strongly agree").

[Figure 3 about here]

Figure 3. Evaluation of national income inequality (pro-equalization is scored high): Percent distribution. 


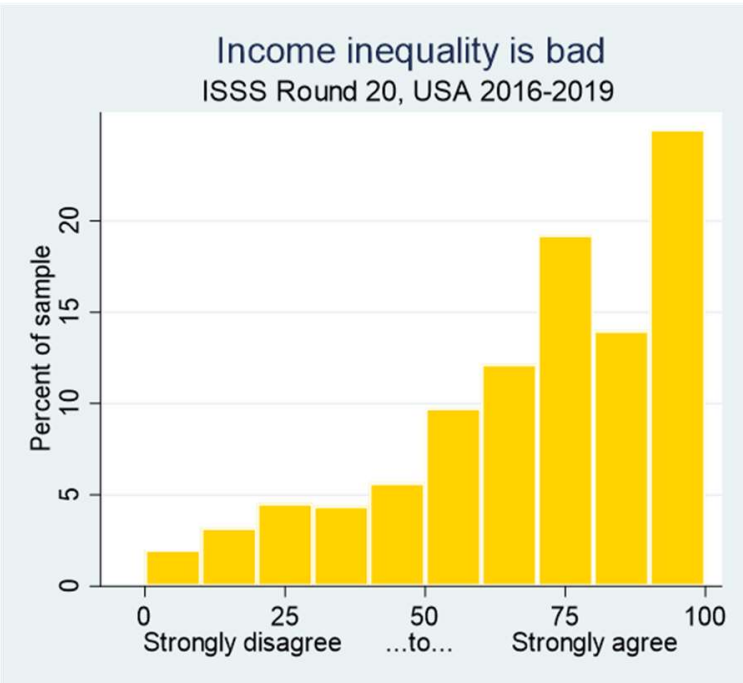

Note: mean $=68$, standard deviation $=25, N=4,274$

\section{Analytic results}

We turn next to the analytic results, estimating first the total standardized effect of envy on support for reducing income inequality (Table 3, Column 1). Next, we enter blocks of control variables, following a temporal and structural logic: Column 2 represents a model augmenting Column 1 with demographic and basic socialization variables emphasizing social -structural aspects of the family of origin. Then we include an important cultural dimension of the family of origin: Column 3 gives the standardized regression coefficients for the Column 2 model augmented by parents' political party. Next, we also begin to include the respondent's own social stratification characteristics, educational attainment, occupational status, and income (Column 4). Then we control for perceived self-interest, whether respondent thinks that her or she personally would gain financially from a reduction in income inequality. This gives us a more distilled version of the envy effect - even aside from any potential gains, do we still find that more envious people want to reduce income inequality (Column 5)? Finally, we filter out the effect of adherence to the Democratic Party and examine the direct effect of income envy on attitude towards income equalization, net of all these potential confounding and intermediate variables (Column 6).

[insert Table 3 about here] 
Table 3. Influences on attitudes toward reducing income inequality. Total effects in dashed blue outline, assuming the block recursive causal order shown; direct effects in column 6; and indirect effects are the difference between the two. OLS standardized regression coefficients. International Social Science Survey Round 20, USA 2016-2019. Coefficients not significantly different from zero at $p<.05$ in grey.

\begin{tabular}{|c|c|c|c|c|c|c|}
\hline & \multicolumn{6}{|c|}{ Favors reducing income inequality } \\
\hline & $(1)$ & $(2)$ & $(3)$ & (4) & $(5)$ & $\begin{array}{l}\text { Direct } \\
\text { effect (6) }\end{array}$ \\
\hline Envy & $0.23^{* * *}$ & $0.24^{* * *}$ & $0.24^{* * *}$ & $0.24^{* * *}$ & $0.17^{* * *}$ & $0.14^{* * *}$ \\
\hline Age & & 0.00 & 0.00 & 0.00 & 0.00 & 0.01 \\
\hline Male & & $-0.04 *$ & $-0.04 * *$ & $-0.04 *$ & -0.03 & 0.00 \\
\hline Parents' education & & -0.01 & -0.01 & 0.00 & 0.02 & -0.01 \\
\hline Churchgoing at age 14 & & 0.00 & 0.02 & 0.03 & 0.02 & 0.02 \\
\hline Parents' occupation & & 0.01 & 0.02 & 0.04 & 0.01 & 0.02 \\
\hline Parents' political party & & & $0.19 * * *$ & $0.18^{* * *}$ & $0.16^{* * *}$ & -0.01 \\
\hline Education & & & & 0.02 & 0.03 & 0.00 \\
\hline Occupational status & & & & -0.01 & 0.01 & 0.01 \\
\hline Family income (In) & & & & $-0.16 * * *$ & $-0.10 * * *$ & $-0.07^{* * *}$ \\
\hline Perceived self-interest & & & & & $0.32 * * *$ & $0.28^{* * *}$ \\
\hline Democratic party & & & & & & $0.43^{* * *}$ \\
\hline Wave 2016 (reference) & & & & & & -- \\
\hline Wave 2017 & & & & & & 0.00 \\
\hline Wave 2019 & & & & & & -0.01 \\
\hline R-squared & 0.05 & 0.06 & 0.09 & 0.12 & 0.21 & 0.36 \\
\hline Cases & 4,270 & 3,948 & 3,948 & 3,606 & 3,603 & 3,438 \\
\hline
\end{tabular}

When entered on its own, envy moderately strongly enhances the view that there is too much income inequality/ that income inequality should be reduced (Table 3, Column 1). The standardized regression coefficient of 0.23 is in the strong range (0.20 to 0.29$)$. The more envious you are, the more you evaluate income inequality as too big, the more you see the income gap between rich and poor as too wide, the more averse you are to income inequality.

The strength of envy's impact on evaluation of income inequality remains in the strong range at 0.24 when we take into account the potential effects of demographic variables and stratification-related family background (Table 3, Column 2). Including these additional variables lifts the adjusted R-squared slightly from .05 to .06, but in this new set of variables only gender has a statistically significant effect. Even it is only in the 
"weak but worth keeping in mind" range (absolute values of .05 to .10) for standardized regression coefficients.

However, that does not mean that all effects of one's origins vanish like writing on the water. Instead, the political subculture of one's childhood is a formative influence on these attitudes. Parents' political party has a standardized regression coefficient of 19 at the top of the moderately strong range (absolute value of .10 to .19) which is, of course, statistically significant (Column 3). This augmentation to the model boosts the R-squared from $6 \%$ to $9 \%$. A key result for our purposes is that including parents' party explains additional variance in inequality aversion, but does not reduce the important effect of envy, 0.23. Thus, the more the family home leant towards the Democratic Party during one's childhood, the more one tends, as an adult decades later, to evaluate income differences in our society as too large, net of the material conditions and religious behavior of the family of origin. But this does not account for envy's effect: The long-term effect of parents' party does NOT imply Democratic parents teach their children to envy the rich. Instead, it is other schemas, attitudes, values, and feelings associated with parents' political orientation that leave lasting impressions.

Leaping forward in the life cycle into the respondent's current adulthood stage, adding the effects of current social stratification characteristics into the model leaves the effect of envy unchanged at .24 (Column 4). Adding this set of influences boosts the adjusted R-squared from $9 \%$ to $12 \%$, but the only one with a statistically significant impact is family income, with a standardized regression coefficient of 0.16 , which puts it in the moderately strong range. Augmenting the model with these stratification-related variables leaves intact the effects of variables that were statistically significant in the previous model - envy's effect is unchanged and the effect parents' party is diminished little, if at all.

Envy's effect shrinks but about $1 / 3$ from .24 to .17 when we include a specific measure of self-interest - perceived personal gain from redistribution - into the model (Column 5). Even with this reduction, it remains well into the "moderately strong" range (.10 to .19). This implies that income envy is correlated with covetousness (wanting what the other has) but also contains a substantial separate component of envy per se. Perceived selfinterest is very strong effect on its own (standardized regression coefficient of 0.32 ) and 
including it lifts the R-squared from $12 \%$ to $21 \%$. As the R-squared change suggests, this is mostly an additional channel of influence. Shrinkages in the effects not only of envy, but also of parents' party, and current family income suggest that these influences included a small self-interest component, but were mostly separate from that.

Including respondent's own political party affiliation into the model trims the envy effect down from .17 to .14 (Column 6): The envious tend to be somewhat attracted to the Democrats, the unenvious to the Republicans, all else equal. ${ }^{4}$

Current political party has a very strong effect on evaluations of income inequality, with a standardized regression coefficient of fully 0.43 which puts it in the "very strong" range (absolute value over 0.3 ). It also partially mediates the effects of the other significant variables, self-interest and family income, reducing their direct effects and, moreover, reducing the effect of parents' party to a point estimate near zero and statistical nonsignificance. Note that the causal direction assumed in the model (from party to inequality attitude, with no reciprocal causation) is justified by a supplementary SEM analysis that allows both effects, but only the effect of party on inequality attitude is statistically significant (Appendix E).

The importance of party revealed in these results prompted further exploration of the possibility that income envy might have different effects among Democrats and Republicans. To this end, we estimated a model including a multiplicative interaction term that allows (but does not require) the effect of envy to differ by party, net of the other influences previously described. The results are striking (Figure 4). Among Democrats, income envy has no further effect on inequality aversion: From the least envious to the most envious, all are highly and equally averse to inequality, all else equal averaging about 80 points out of 100 on the scale. (The solid green lines show the confidence interval for the predicted values from the regression equation.) The least envious Independents are considerably less opposed to inequality than their peers among the Democrats (predicted mean in the high 50s as opposed to around 80), but as envy escalates, the inequality aversion of the Independents converges towards that of the Democrats (dashed line in beige). Finally, income envy matters greatly to the

\footnotetext{
${ }^{4}$ Controlling for the other variables in our model, envy has a standardized effect on party identification of .08 $(\mathrm{t}=3.77, \mathrm{p}<.001, \mathrm{~N}=2,009)$.
} 
inequality aversion of Republicans. The least envious Republicans do not see income inequality as too high or requiring redistribution: they have inequality aversion scores in the 30s, well below the neutral point, and roughly 50 points below otherwise similar Democrats. But, among Republicans, as income envy climbs, income inequality aversion rises steeply. The most envious Republicans are roughly 30 points out of 100 more opposed to income inequality than are their envy-free Republican peers.

Moreover, the most envious Republicans have inequality attitudes much closer to their Democrat peers: they are only about 20 points out of 100 less inequality averse (compared to the yawning gulf of roughly 50 points between the least envious of both parties).

[Insert Figure 4 about here]

Figure 4 .

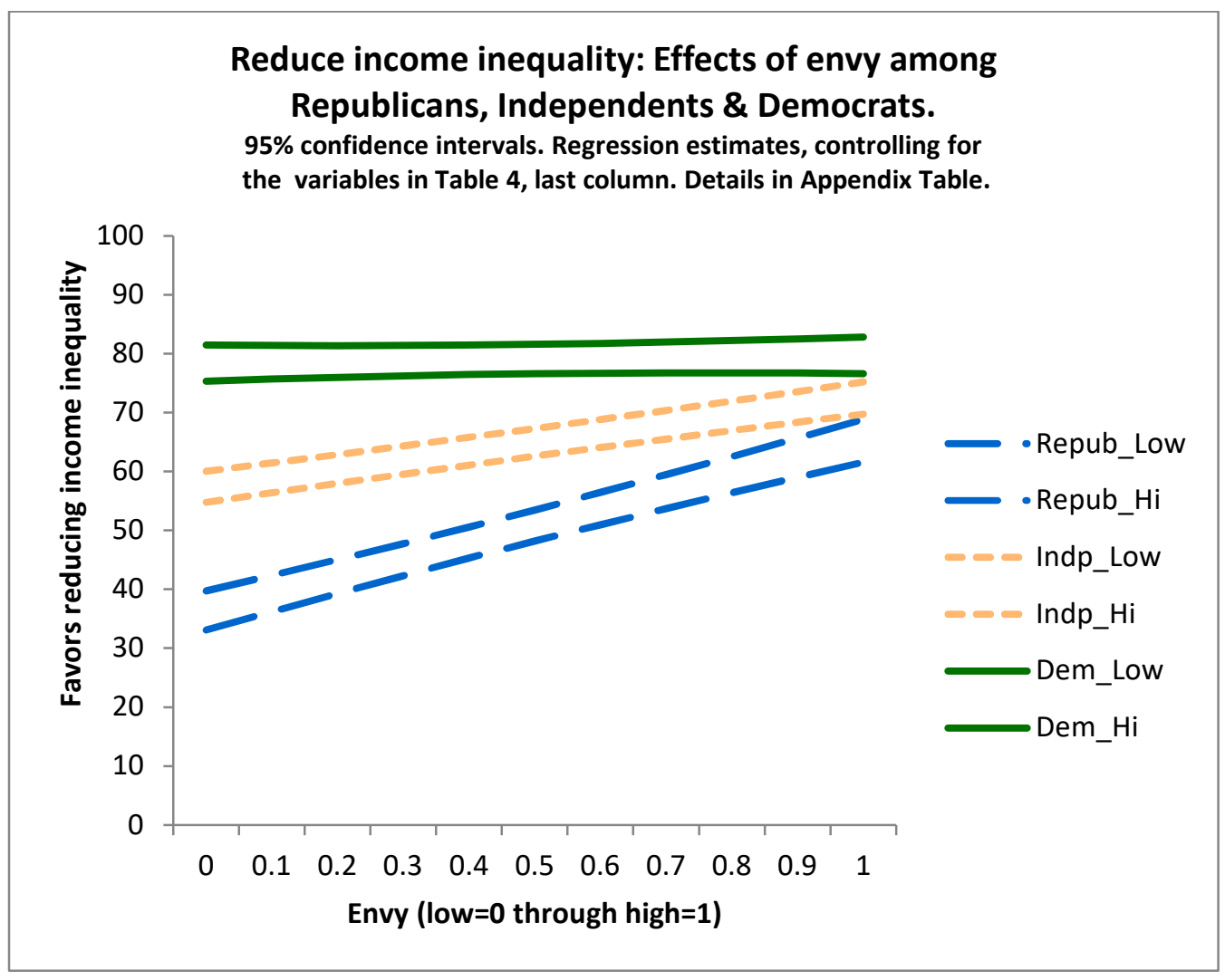


In sum, we find that income envy has a moderately strong bivariate link with attitudes towards income inequality (also called attitude toward redistribution or inequality aversion). Moreover, the strength of this relationship persists net of primary socialization influences, both stratification-related and cultural (parents' party); net of status attainment in education, occupation, and income; and net of perceived selfinterest. The direct effect of envy remains in the moderately strong range when we also take into account respondent's current political party preference.

In more detail, the finding that there are no total effects of the family of origin's stratification position is of theoretical importance because it means that the self-interest and reference groups associated with social structural position in childhood do not have lasting consequences for later moral evaluations of income inequality. The material constraints and opportunities of one's upbringing leave little or no mark on one's judgement in adulthood about whether contemporary income differences are too large. The fact that the family of origin's attendance at worship services has no discernible lasting impact on inequality evaluations aligns with considerable prior research suggesting that although religious commitments may encourage volunteer work and charitable giving, they do not generally influence attitudes on inequality and redistribution.

Envy's impact remains unchanged when we also include parents' party into the model. Parents' party does have a moderately strong total effect, and indeed, it is the second most important influence on redistribution attitudes at this point in the modeling process. This is of theoretical importance because it suggests that the enduring impact of the political milieu of one's childhood does not come about because Democrat parents envy the rich (and so role model envy for their children) whereas Republican parents are less covetous. Instead, envy seems to amplify income inequality aversion on its own, untouched by parent's party. In a separate channel of influence, parents' party influences income inequality attitudes, but that has little to do with envy.

The picture changes somewhat, but surprisingly little, when we include current social stratification position and perceived self-interest into the model. Self-interest has a very 
strong effect, but its inclusion does not eliminate the effects that were significant in the prior model. For our focal predictor, envy, about 2/3 of the previous effect remains, so its effect stimulating inequality aversion/ support for redistribution is still in the moderately strong range. Most people think they would gain if incomes were to become more equal, and the more one thinks one would gain, the greater one's disapprobation of the current income distribution as too unequal, but this only explains part of the income-envy effect. Note that the fact that including perceived self-interest into the model leaves income having a moderately strong direct effect suggests that most of the income effect reflects reference group norms and perceptions of society as a whole that are generalizations from one's narrow socioeconomic milieu. This is important because nearly all prior research interprets stratification and social-class-related effects as reflecting self-interest. These effects are rarely large (Evans and Kelley 2018a, Fernandez and Jaime-Castillo 2018, Lin, Kamo and Slack 2018, Schmidt-Catran 2016), probably because reference groups include some diversity of SES (the stellar student in a working-class family, the working-class parents of the spouse of the offspring of a middle-class family, etc.) and perhaps because entertainment media incidentally cast light on many different walks of life.

Adding current political party affiliation into the model reduces envy's effect further, albeit still leaving it in the moderately strong range. This suggests that part of the reason that envious people judge income inequality to be excessive is that they are attracted to the Democratic party and accept disapprobation of inequality as part of the "package deal". More speculatively, they might be attracted to the Democrats' redistributive policy orientation because the "take from the rich" part provides a legitimate, morally acceptable mechanism for "cutting down the tall poppies". Party preference has a very strong impact on desire for inequality reduction (strong Democrats 80 compared to strong Republicans 50), a substantial additional influence, as well as sweeping portions of the other influences in its train. Yet, even after taking respondent's party into account, envy retains a moderately large separate effect on evaluations of income inequality (those free of envy score 50 compared to 73 for the highly envious, other things being equal).

In short, evaluating income inequality as too high or too low is mainly a matter of party politics, especially conformity to a "party line". Beyond that there is some perceived self- 
interest, a third as important as politics: Those who expect to gain from greater equality want their banquet to begin. Further beyond that, a fifth as important as politics, is the green monster: The envious would bring down the rich. Only the prosperous would give the rich a bit of support.

Further exploration revealed that income envy has no direct effect on inequality aversion among Democrats: Inequality aversion is high regardless of envy. By contrast, envy is highly influential among Republicans. There is more disagreement between envious and envy-free Republicans over the morality of income inequality than there is, on average, between adherents of the two parties.

Thus, this paper makes several contributions. (1) It contributes to the sociology of emotions by demonstrating the importance of a particular emotion, envy of the rich, far beyond the personal realm and controlling for a broad array of potentially confounding socialization and structural-location variables. (2) It contributes to the study of attitudes towards inequality by demonstrating that emotions are not mere transmitters of social structural position, but, rather, are separate influences with importance on a par with the structural and material influences that have commanded so much attention in this domain for so long. The focus of this paper was specifically on envy, but future research would do well to elaborate the model used here with other emotions, to help us understand the role of emotions in our public life.

Scholars have called for expansion of the study of emotions into cross-cultural research in order to better understand variation in moral stances on income inequality (Collins 2019, Hitlin and Harkness 2018, Li, Zuckerman and Diener 2019) . Our one-country study has not contributed to that directly, but may help lay the groundwork through the development of a reliable and compact measure of income envy and through the demonstration of the link between income envy and moral views about income inequality. Next, research can ask how income envy varies cross-culturally and whether its links to moral evaluations of income and wealth inequality differ by national context. Our finding of the substantial differences between Democrats and Republicans in the US suggest that there will be substantial cultural differences in (1) the prevalence of income envy and (2) that the link between income envy and moral stances on income 
inequality will be large in more market-oriented societies and weak or absent in strong welfare states (Collins 2019, Hitlin and Harkness 2018, Li, Zuckerman and Diener 2019).

\section{Online appendices/ supplementary materials}

Appendix A: Income envy scale: More detail and alternate versions of Item 3.

\section{Further details on the income envy scale}

Any equal-interval scoring generates mathematically identical correlations and standardized coefficients and leads to metric coefficients that differ only by a scaling factor. Likert-type items meet the criteria for treatment as coarsely measured continuous variables which can be scored at equal intervals unless there is evidence to the contrary (Bollen and Barb 1981, Carifio and Perla 2007, Likert 1932, Nowak 2019, O'Brien and Homer 1987).

The motivation for using a multiple-item index is the theoretical view that attitudes are latent or "true" variables of which our measured questionnaire items are imperfect indicators or symptoms. The idea is that no single measured item fully captures the latent variable, but that by incorporating multiple items into an index we draw on the parts they have in common thereby better representing the true attitude. In slightly more technical terms, using multiple items enhances the reliability of measurement which makes for parameter estimates which better approximate the ideal of consistency and unbiasedness (Bollen 1989; Evans and Kelley 2004; Treiman 2009).

The first two items were asked in all three waves. Item 3 ("...vast amount of money..." was asked in Wave 1 and 2, but not in Wave 3. Item 4 ("...lavish lifestyle..." was asked in Wave 3, but not it Waves 1 and 2. Because of the advantages of multiple-item scales in reducing bias and inconsistency, there is a substantial advantage to creating a scale that treats Items 3 and 4 as functional equivalents (also called measurement equivalents), thus making use of all the information at our disposal. For the type of data we have, CFA, IRT, and kindred methods tend to have the same results (Meade and 
Lautenschlager 2004, Stark, Chernyshenko and Drasgow 2006, Tay, Meade and Cao 2014)..$^{5}$

The answers to the first two items are highly correlated in both versions at $0.85-0.88$. In the first 2 waves, the version of Item 3 ("...vast amount of money...") is also highly correlated with the first two (indeed so highly correlated with them at .85 and .90 that it added little information, which suggested swapping it out for a different item that might add more information). The alternate version of Item 3 ("...Lavish lifestyle...") also has very high correlations with the first two items (.79 and .83) suggesting that it is a functional equivalent of its predecessor. Note that the slightly lower correlation very likely reflects the difference in the wording, rather than differences between waves as the correlation between the first two items is closely similar in all waves (see Appendix A for details.) Accordingly, we pool the samples and treat the two versions of Item 3 as a single item.

\section{Alternate versions}

We next address the issue of whether the alternate versions of Item 3 ("...lavish standard of living..." and "vast amount of money..." can be treated as functional equivalents. For the proposed scale items, Table A1 gives the abbreviated item wording (see text for verbatims), the interitem correlations, and the standardized and metric CFA factor loadings. The wording of Items 1 and 2 is the same in both Wave 3 and Waves 1 and 2 and the correlations between them are high and similar (.85 for Wave 3, .88 for Waves 1 and 2). The standardized CFA loadings for these items are nearly identical in Wave 3 (.90 and .95) compared to Waves 1 and 2 (.90 and .96). The correlations of Item 3 in the "...lavish standard of living..." version are tight with Items 1 and 2: .79 and .83, and the standardized CFA factor loading is a strong .87. The picture is similar, with connections fractionally tighter in Waves 1 and 2. The correlations of Item 3 with Items 1 and 2 are .85 and .90 and the standardized CFA factor loading is 0.93 . These results justify treating the alternate versions of Item 3 as functional equivalents and using them

${ }_{5}^{5}$ CFA and IRT are largely interchangeable for scales with few items and large samples. IRT is better for identifying items in large batteries that distinguish finely at the extremes (e.g. IQ tests or achievement tests with hundreds of items). 
together with Items 1 and 2 to create a 3-item scale to use with a pooled sample of all 3 waves.

[Table A1 about here]

Table A1. Inter-item correlations for items in the envy scale.

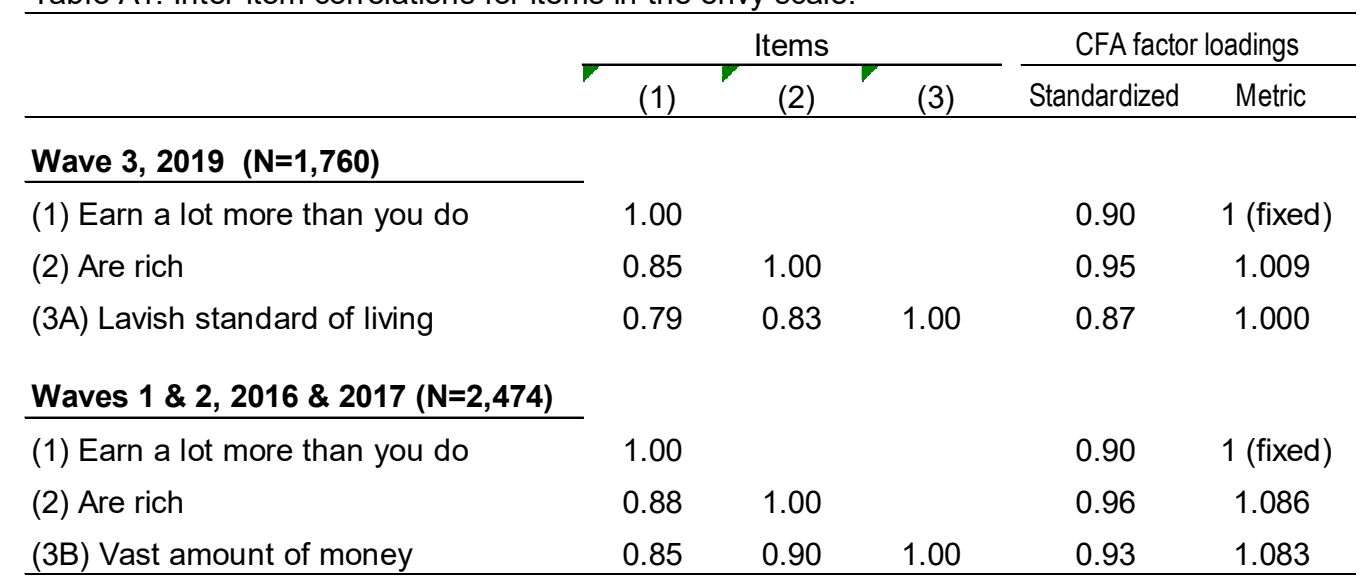

[Source] International Social Science Survey Round 20, USA 2016-2017.

[Note] ltem 3 is "...vast amount of money..." in Waves 1 and 2 and the (functionally equivalent) "...lavish standard of living..." in Wave 3.

\section{Appendix B:Cross-national perspective on redistribution}

In a broad array of nations, the citizenry is neutral to strongly inequality averse, as has also been found in prior research (Arsenio 2018, Evans and Kelley 2018a, Rozer and Kraaykamp 2013, Schmidt-Catran 2016). In international perspective, support for a more equal income distribution is lower in the US than any other nation for which we have the relevant data (Table B1). The difference is about 20 points out of 100 , the US at 57 points with most other nations in the high 70s or low 80s. Many a European would not be surprised; American exceptionalism has long been a stereotype in European politics.

[Table B1 about here]

Table B1. Inequality aversion/ support for reducing income inequality (Means). 45 Nations, 1987-2009. 
Support for reducing income inequality (points out of 100) by nation. 45 nations, $1987-2009$.

In order from most support to least. Communist and formerly Communist nations in red; English speaking nations in green.

\begin{tabular}{|c|c|c|}
\hline & Mean & Cases \\
\hline 804. Ukraine & 90 & 2,012 \\
\hline 620. Portugal & 89 & 2,144 \\
\hline 100. Bulgaria & 86 & 4,494 \\
\hline 792. Turkey & 85 & 1,569 \\
\hline 191. Croatia & 84 & 1,201 \\
\hline 643. Russia & 83 & 5,291 \\
\hline 233. Estonia & 83 & 1,005 \\
\hline 278. Germany-East & 83 & 2,044 \\
\hline 428. Latvia & 83 & 2,169 \\
\hline 350. Hungary: Market & 83 & 3,468 \\
\hline 703. Slovakia & 82 & 2,664 \\
\hline 705. Slovenia & 82 & 3,120 \\
\hline 250. France & 81 & 4,706 \\
\hline 376. Israel & 81 & 2,401 \\
\hline 380. Italy & 81 & 996 \\
\hline 32. Argentina & 79 & 1,133 \\
\hline 156. China & 79 & 3,010 \\
\hline 410. Korea, Rep (South) & 78 & 1,599 \\
\hline 618. Poland: Market & 78 & 9,349 \\
\hline 724. Spain & 77 & 2,426 \\
\hline 40. Austria & 77 & 3,007 \\
\hline 352. Iceland & 77 & 947 \\
\hline 152. Chile & 77 & 3,008 \\
\hline 710. South Africa & 77 & 3,305 \\
\hline 246. Finland & 76 & 2,600 \\
\hline 203. Czech Republic & 76 & 3,717 \\
\hline 349. Hungary: Red & 76 & 2,606 \\
\hline 158. Taiwan & 74 & 2,026 \\
\hline 617. Poland: Red & 74 & 2,336 \\
\hline 372. Ireland & 72 & 972 \\
\hline 56. Belgium & 71 & 1,115 \\
\hline 826. United Kingdom & 70 & 4,040 \\
\hline 280. Germany-West & 69 & 5,571 \\
\hline 392. Japan & 69 & 2,621 \\
\hline 828. N Ireland & 68 & 830 \\
\hline 752. Sweden & 67 & 3,036 \\
\hline 756. Switzerland & 64 & 3,474 \\
\hline 578. Norway & 64 & 4,262 \\
\hline 528. Netherlands & 64 & 4,979 \\
\hline 554. New Zealand & 63 & 3,282 \\
\hline 124. Canada & 62 & 1,978 \\
\hline 608. Philippines & 62 & 3,600 \\
\hline 208. Denmark & 61 & 1,518 \\
\hline 36. Australia & 60 & 10,069 \\
\hline 840. United States & 57 & 5,690 \\
\hline
\end{tabular}

Source: World Inequality Study, Version 2.1 
But the matter is actually more complex. To assess whether the determinants of inequality aversion/ attitudes towards inequality differ in the US (if they did, the findings about envy clearly would not generalize), we estimated a multilevel model (GLS, random intercepts, fixed coefficients) of the two-item inequality aversion scale mentioned in text, including both individual-level stratification variables and contextual variables (Appendix Table B2).

The relatively weak effects of the individual-level variables echo the findings for prior research; socioeconomic development and actual inequality fail to have significant effects; the dominant effects are cultural or institutional: (1) A Communist legacy, and (2) being in an English-speaking country.

\section{[Insert Appendix Table B2 about here]}

\section{Appendix Table B2.}

\begin{tabular}{|c|c|c|c|}
\hline & Standardized & $\begin{array}{l}\text { Metric (first } \\
\text { difference) }\end{array}$ & Comparison for first differences (low vs high) \\
\hline \multicolumn{4}{|l|}{ Individual characteristics } \\
\hline Male & $-0.06 * * *$ & -3 & No vs yes \\
\hline Education & $-0.07^{* * *}$ & -4 & Primary vs university \\
\hline Occupational status & $-0.06^{* * *}$ & -6 & Lowest (farm laborer) vs highest (professional) \\
\hline Family income (In) & -0.12 *** & -8 & Lowest $10 \%$ vs highest $10 \%$ in the nation \\
\hline \multicolumn{4}{|c|}{ Characteristics of the nation } \\
\hline GDP per capita & 0.02 & n.s. & Not statistically significant \\
\hline Income inequality (Gini) & 0.04 & n.s. & Not statistically significant \\
\hline English speaking nation & $-0.18^{* * *}$ & -10 & No vs yes \\
\hline Ex-Communist nation & $0.17^{* * *}$ & 9 & No vs yes \\
\hline USA & -0.06 & n.s. & Not statistically significant \\
\hline R-squared & 0.14 & & \\
\hline Rho & 0.082 & & \\
\hline N people & 103,105 & & \\
\hline N Surveys & 108 & & \\
\hline N Societies & 44 & & \\
\hline
\end{tabular}




\section{Formerly Communist nations}

In general people in formerly Communist nations have a strong tendency to evaluate their country's income inequality as excessive - they have seen a vast growth in income inequality in the post-Communist era. It seems likely that it is historical change in the actual distribution that drives their views (Kelley and Zagorski 2005, Kolczynska and Merry 2016, Kuhn 2015, Smith and Mateju 2012, Zagorski 1996). Hungarians (residents of the sole nation for which we have the relevant data in the Communist era) held much more neutral views of their income distribution in 1987 ('Hungary Red' in the table) while Hungarians in the post-Communist era ('Hungary Market' in the table) see too much income inequality in their society.

The multilevel analysis above controlling demographic and SES variables as well as national-level variables (formerly Communist, English speaking, a dummy variable for the US, and actual inequality as measured by the Gini coefficient) shows that formerly Communist nations are, other things being equal, some 7 points more in favor of equalizing incomes ( $\mathrm{z}=3.54, \mathrm{p}<.001, \mathrm{~N}=45$ nations and 71,613 individual respondents) which suggests that the effects of Communism increasing inequality aversion found in earlier research (Gijsberts 2002) persists long after Communism ended in these countries (Ignacz 2018).

\section{English speaking nations}

English-speaking nations are, on the whole, much less averse to income inequality. The difference, again net of everything else, is fully 10 points $(\mathrm{z}=-3.32, \mathrm{p}<.01)$. This 'AngloAmerican' tendency to prefer free markets economically, and to tolerate the consequences, is well known from previous research (Beramendi and Rehm 2016, Castles 2010, Kelley and Evans 1995, Osberg and Smeeding 2006, Zagorski 1996). Historians trace its roots to the late Middle Ages (Macfarlane 1978). This grouping appears under many labels, for example a map of the individualism/collectivism distinction closely resembles it (e.g. Hofstede nd)

\section{American exceptionalism? Probably not}

Taking all this into account, Americans are probably not noticeably different in their taste for reducing income inequality. Once we have taken into account that Americans have not been subject to Communist rule, and that they are indeed English-speaking 
(pace Professor Higgins) and so imbued with Anglo-Celtic individualism and AngloAmerican historical experiences, they are not significantly different from other nations $(\mathrm{z}=-0.95, \mathrm{p}=.34)$. The point estimate still leaves them 6 or 7 points below what would be predicted from the worldwide pattern, but is a small enough difference that it could well be chance.

A Scottish verdict of "unproven" exceptionalism thus seems appropriate. ${ }^{6}$ This suggests that generalization of our results to the wider world is not silly, but should be treated as a hypothesis rather than a solid statistical inference.

This suggests that although we have a one-country sample it is reasonable to regard it as likely that similar results will be found in other advanced nations without a Communist legacy.

Appendix C: Measurement of control variables

More on perceived self-interest

Prior research generally finds effects of income and other stratification-related variables on these attitudes that are weaker than expected. This is true in our cross-cultural data as well where education and occupational status have only small effects (standardized coefficients under .10) and even family income has only a modest .12 standardized effect (Appendix B, Table B2).

Thus, the link between personal income and other stratification variables, on the one hand, and potential gains and losses from policies reducing income inequality seems to be weak. Comparison of the real-world policies creating low inequality societies, such as in Sweden and other Nordic nations, suggests that the policies are numerous and complex with implications that are by no means obvious for old and young, women and men, well-educated and poorly educated, those in the labor market and out of it, the able and the not so able, those in high status jobs and those in modest ones, and

\footnotetext{
${ }^{6}$ Full details on the World Inequality Study data and our multilevel analysis of it are available on request from the authors.
} 
those on the political left versus those on the right. The place someone can expect to have in a more egalitarian society is by no means certain, nor obvious.

We therefore asked explicitly about people's perceived self-interest in redistribution. This new measure (dealt with in detail in a separate publication) is only a control variable here, but it is worth mentioning because its inclusion is important in reducing confounding variables bias and because it is new and hence its behavior is not yet familiar. The verbatim:

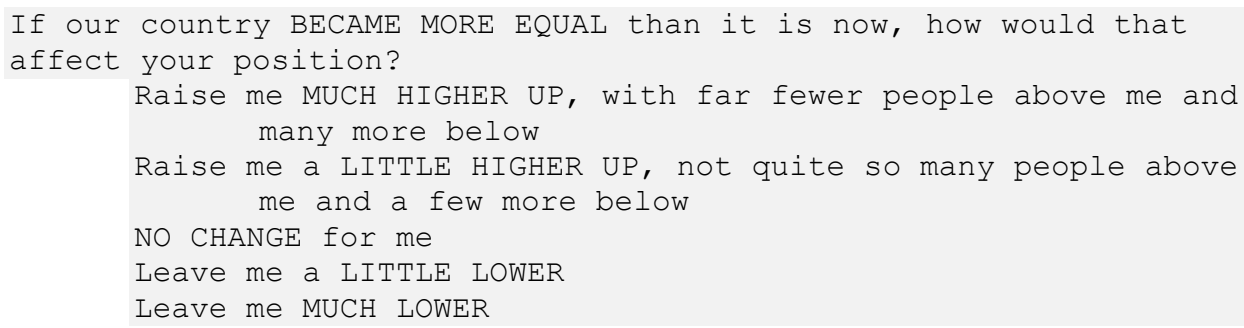

It is scored in equal intervals from- 1 (much lower) through 0 (no change) to +1 (much higher). It is located in the questionnaire in the context of a module of questions about income inequality, so respondents interpret it with that priming.

In Wave 3 we added a companion item elsewhere in the questionnaire, scored it similarly, and averaged the two in the scale used here:

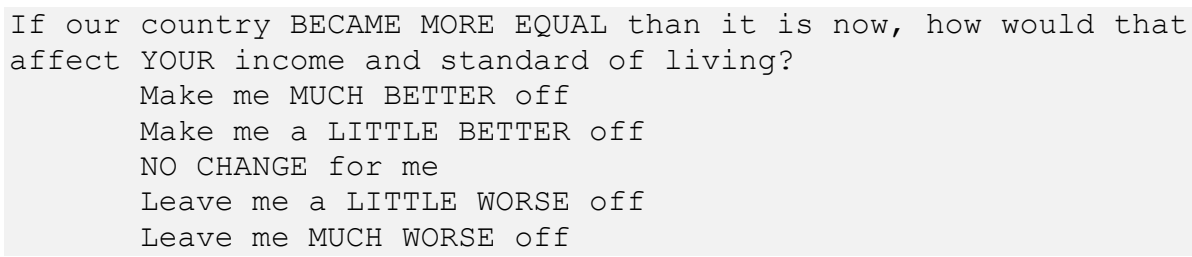

All this is not simply an alternative representation of income. A two-thirds majority expect to gain and most of the rest expect to be unaffected. Even very prosperous people believe they would gain from a more equal society. For example, those with a family income over $\$ 150,000$ per year - which is higher than some $85 \%$ of Americans mostly believe they would gain, or at least not lose, if incomes became more equal (Figure 1 in light blue).

[Figure 1 about here]

Figure 1 


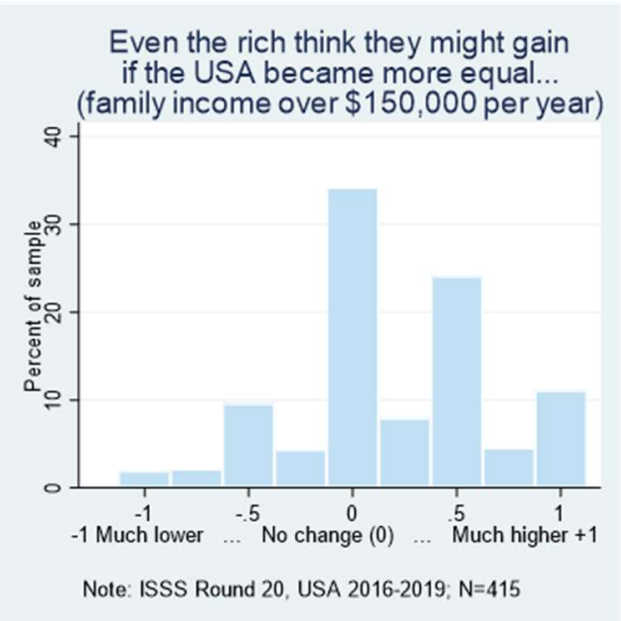

Adjusting for differences in demographic factors, family background, education, and occupational status, a regression analysis (details not shown) suggests that higher income families are indeed less likely to think they would benefit - but only by a moderate amount (standardized regression coefficient for logged family income $=-.17$, $\mathrm{p}<.001, \mathrm{~N}=3,606$ ) and with their expectation still indicating that they expect to gain, on average. Specifically, for someone with $\$ 150,000$ per year - substantially higher income than the vast majority of Americans - the predicted response would be 0.25 , halfway between "no change for me" and "leave me a little better off/ higher up".

Whether this perception is realistic or not is another question. But that is what people believe and it is (as we will see) very real in its consequences. ${ }^{7}$

This may well reflect the well known fact that most people believe they rank in the middle of society, not at the top or the bottom (e.g. Curtis 2013, Evans, Kelley and Kolosi 1992, Evans and Kelley 2017, Markus 2017). Perceived self-interest in inequality reduction is, of course, a topic of major interest in itself, but for present purposes, perceived self-interest is just a control variable, enabling us to focus on income envy, pure and simple.

\footnotetext{
7 The way a more equal society could best be achieved is by no means clear. A more progressive income tax alone would surely leave high income families worse off. But European experience (for example in the famously egalitarian Nordic nations) suggests many more labor market, regulatory, tax, health, and retirement system changes are likely as well. The short-term costs and benefits of these are hard to estimate, depending on age, gender, education, ability, family composition, labor force preferences, and many other things. The long-term costs and benefits as society adjusts to all these changes are harder yet to forecast.
} 


\section{Other control variables}

Age is measured in single years.

Our gender variable is Male, scored with female as the reference category and male as the deviation category (male $=1$, female 0 ).

Churchgoing at age 14 is measured by a direct question about the frequency of attendance at public worship services.

Education is measured in years completed up to a maximum of 20. Parents' education was measured similarly, with mother's and father's averaged (Korupp, Ganzeboom and Van der Lippe 2002).

Occupational status is measured by a (surprisingly good) direct self-coded question and scored in Worldwide Status Scores (Kelley 1990a, 1990b; Kelley and Evans 2016). Scores range from zero (farm laborers) through 1.0 (higher professionals). Parents' occupational status is measured the same way from direct questions asking respondents about their parents' work when respondent was growing up. If both mother and father worked, their scores were averaged.

Family income is current income for respondent and their current family, in thousands of US dollars, based on a direct question. We analyze its natural log because the differences in inequality attitudes tend to be larger per unit gain in income for low and middle incomes than for high incomes.

Political party identification is measured by a composite of party preference and recent voting patterns. Those without preference, or not voting, are scored in the middle, halfway between strong Democrats and strong Republicans. Parents' party is based only on party, not vote. Mother's and father's preferences are averaged. 
Table D-1. Correlations among all the variables in the full model. Complete case analysis (listwise deletion), $\mathrm{N}=3093$.

Focal variables
(a)
(b)
(c)
(d)
(e) (f)
(g)
(h)
(i)
(j)
(k) (l) (m)

Inequality

\begin{tabular}{llllll} 
aversion (a) & 1.00 & & & \\
\hline Envy (b) & 0.26 & 1.00 & & \\
\hdashline Demographics & & & & \\
Age (c) & -0.01 & -0.04 & 1.00 & \\
Male (d) & -0.04 & -0.01 & 0.00 & 1.00
\end{tabular}

Parents'

characteristics

$\begin{array}{llllll}\text { Education (e) } & 0.04 & 0.12 & -0.02 & 0.06 & 1.00\end{array}$

$\begin{array}{lllllll}\text { Churchgoing (f) } & -0.01 & -0.05 & 0.00 & -0.04 & 0.01 & 1.00\end{array}$

$\begin{array}{llllllll}\text { Occupation (g) } & 0.04 & 0.13 & 0.00 & 0.08 & 0.57 & 0.06 & 1.00\end{array}$

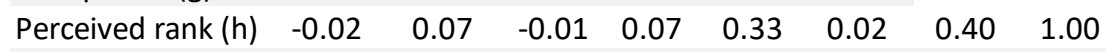

Party (i)

$\begin{array}{lllllllll}0.18 & -0.03 & 0.02 & -0.01 & -0.07 & -0.10 & -0.08 & -0.10 & 1.00\end{array}$

Respondent's

characteristics

$\begin{array}{lllllllllll}\text { Education (j) } & -0.01 & 0.05 & 0.01 & 0.09 & 0.31 & 0.05 & 0.25 & 0.13 & -0.02 & 1.00\end{array}$

$\begin{array}{llllllllllll}\text { Occupation (k) } & -0.03 & 0.03 & 0.02 & 0.04 & 0.17 & 0.04 & 0.29 & 0.15 & 0.00 & 0.46 & 1.00\end{array}$

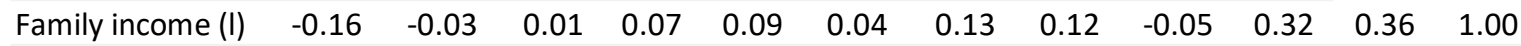

$\begin{array}{lllllllllllllll}\text { Self-interest }(\mathrm{m}) & 0.39 & 0.23 & -0.02 & -0.05 & -0.04 & 0.03 & 0.00 & -0.02 & 0.08 & -0.09 & -0.14 & -0.20 & 1.00\end{array}$

\begin{tabular}{llllllllllllll} 
Party $(\mathrm{n})$ & 0.49 & 0.09 & -0.01 & -0.08 & 0.06 & -0.04 & 0.02 & -0.03 & 0.39 & 0.03 & 0.02 & -0.10 & 0.16 \\
\hline
\end{tabular}

Note: Variable measurements are given in the Measurement section and in Appendix B. Note that strong Democrats are scored high on "Party" and that self-interest is perceived self-interest. Focal correlation is highlighted in green.

Alternate rows are shaded grey to facilitate reading across long rows. 
Appendix E: Reciprocal effects between envy and party identification: An SEM estimate

This appendix addresses an issue of causal order: whether political party identification shapes views about reducing income inequality (as we have assumed in our analysis) or, instead, whether views about income inequality help determine the political party that people join so that some or all the causal effect goes the other way.

The answer is that attitudes toward reducing income inequality has no statistically significant impact on Democratic party identification. The influence is all the other way around, as we have assumed in the main analysis.

These are structural equation estimates (see, for example, Bollen 1985). The identifying assumption - a relatively safe one as these difficult matters go - is that parents' party is correlated with respondent's views about reducing inequality only indirectly through its impact on respondent's party identification. As is usual in reciprocal causation models this assumption must be justified on theoretical and logical grounds, it cannot be tested directly. Here the assumption seems entirely plausible and quite consistent with a vast literature on the massive influence of parents' politics as discussed "around the dinner table". 
Influences on attitudes toward reducing income inequality and political party identification: Reciprocal effects. The identifying assumption is that parents' political party identification only matters to views about inequality reduction INDIRECTLY through its influence on respondent's political party identification. Structural equation estimates, standardized coefficients. USA 2016-2017.

\begin{tabular}{ccccc}
\hline \multicolumn{3}{c}{ Standard } \\
Coefficient & error & $\mathrm{z}$ & $\mathrm{p}<$ \\
\cline { 2 - 5 } & $(1)$ & $(2)$ & $(3)$ & $(4)$ \\
\hline
\end{tabular}

\section{A. Effects on Democratic Party} identification ( $r$-sq = .227)

\begin{tabular}{|c|c|c|c|c|}
\hline For reducing income inequality & 0.03 & 0.062 & 0.46 & 0.643 \\
\hline Envy & 0.07 & 0.022 & 3.34 & 0.001 \\
\hline Age & -0.08 & 0.021 & -3.67 & 0.000 \\
\hline Male & -0.06 & 0.020 & -3.19 & 0.001 \\
\hline Parents' education & 0.05 & 0.026 & 1.98 & 0.048 \\
\hline Church going at age 14 & 0.02 & 0.020 & 1.17 & 0.242 \\
\hline Parents' occupation & 0.03 & 0.027 & 1.26 & 0.206 \\
\hline Parents' subjective rank & -0.03 & 0.022 & -1.15 & 0.252 \\
\hline Parents' political party & 0.38 & 0.021 & 18.02 & 0.000 \\
\hline Education & 0.06 & 0.023 & 2.59 & 0.010 \\
\hline Occupational status & 0.03 & 0.023 & 1.22 & 0.224 \\
\hline Family income (In) & -0.08 & 0.023 & -3.51 & 0.000 \\
\hline Expects personal gain from equality & 0.11 & 0.025 & 4.23 & 0.000 \\
\hline [intercept] & 0.64 & 0.232 & 2.77 & 0.006 \\
\hline
\end{tabular}

B. Effects on views about reducing income inequality $(r$-sq $=.354)$

\begin{tabular}{|c|c|c|c|c|}
\hline \\
\hline Democratic party identification & 0.47 & 0.047 & 10.11 & 0.000 \\
\hline Envy & 0.11 & 0.019 & 5.70 & 0.000 \\
\hline Age & -0.01 & 0.020 & -0.52 & 0.601 \\
\hline Male & 0.00 & 0.018 & -0.14 & 0.890 \\
\hline Parents' education & 0.00 & 0.024 & -0.04 & 0.971 \\
\hline Church going at age 14 & 0.01 & 0.018 & 0.76 & 0.445 \\
\hline Parents' occupation & -0.02 & 0.024 & -0.84 & 0.398 \\
\hline Parents' subjective rank & -0.02 & 0.020 & -0.96 & 0.339 \\
\hline \multicolumn{5}{|l|}{ [omitted -- instrumental variable] } \\
\hline Education & 0.01 & 0.021 & 0.33 & 0.743 \\
\hline Occupational status & 0.01 & 0.021 & 0.36 & 0.719 \\
\hline Family income (In) & -0.08 & 0.020 & -4.04 & 0.000 \\
\hline \multirow{4}{*}{$\begin{array}{l}\text { Expects personal gain from equality } \\
\text { [intercept] }\end{array}$} & 0.18 & 0.020 & 9.21 & 0.000 \\
\hline & 2.06 & 0.176 & 11.70 & 0.000 \\
\hline & 0.773 & 0.048 & & \\
\hline & 0.646 & 0.017 & & \\
\hline
\end{tabular}

[Fit] The model is exactly identified, so RMSEA $=0$ and CFI=1. 
Alwin, Duane F. 1992. "Equity Theory." Pp. 563-75 in Encyclopedia of Sociology, edited by E. F. Borgatta and M. L. Borgatta. New York: Macmillan.

Alwin, Duane F. and Jon A. Krosnick. 1993. "Aging, Cohorts, and the Stability of Sociopolitical Orientations over the Life Span." American Journal of Sociology 97(1):169-95. doi: doi.org/10.1086/229744.

Aristotle. 350 BCE. "Book 5." Pp. Book 5, Section 3, Part A Paragraph 2 in Nicomachean Ethics. Translated by W. D. Ross. Boston: http://classics.mit.edu/Aristotle/nicomachaen.5.v.html.

Aristotle. 350 BCE "Part 10." in Rhetoric, Book Ii. Boston, MA: MIT: The Internet Classics Archive.

Arsenio, William. 2018. "The Wealth of Nations: International Judgments Regarding Actual and Ideal Resource Distributions." Current Directions in Psychological Science Online before print(Sept ):https://doi.org/10.1177/0963721418762377.

Austen, Siobhan. 1999. "Norms of Inequality." Journal of Economic Issues 33(2):435-42. Austen, Siobhan. 2002. "An International Comparison of Attitudes to Inequality." International Journal of Social Economics 29(3):218-37. doi: 10.1108/03068290210417106.

Bandura, Albert. 2018. "Toward a Psychology of Human Agency." Perspectives on Psychological Science 13(2):130-36. doi: 10.1177/1745691617699280.

Beramendi, Pablo and Philipp Rehm. 2016. "Who Gives, Who Gains? Progressivity and Preferences." Comparative Political Studies 49(4):529-63. doi: 10.1177/0010414015617961.

Bollen, Kenneth A. and Kenney H. Barb. 1981. "Pearson's R and Coarsely Categorized Measures." American Sociological Review 46(2):232-39. doi: 10.2307/2094981.

Boutyline, Andrei and Stephen Vaisey. 2017. "Belief Network Analysis." American Journal of Sociology 122( 5):1371-447. doi: 10.1086/691274.

Brader, Ted and Joshua A. Tucker. 2018. "Unreflective Partisans?". Advances in Political Psychology 39(Supplement 1):137-57. doi: 10.1111/pops.12480.

Brady, David and Amie Bostic. 2015. "Paradoxes of Social Policy: Welfare Transfers, Relative Poverty, and Redistribution Preferences." American Sociological Review 80(2):268-98. doi: https://doi.org/10.1177/0003122415573049.

Breznau, Nate. 2010. "Economic Equality and Social Welfare: Policy Preferences in Five Nations." International Journal of Public Opinion Research 22(4):458-84.

Breznau, Nate and Maureen A. Eger. 2016. "Immigrant Presence, Group Boundaries, and Support for the Welfare State in Western European Societies." Acta Sociologica 59(3):195 - 214. doi: doi: 10.1177/0001699316645168. 
Breznau, Nate. 2017. "Positive Returns and Equilibrium: Simultaneous Feedback between Public Opinion and Social Policy." Policy Studies Journal 45(4):583-612. doi: https://doi.org/10.1111/psj.12171.

Breznau, Nate and Carola Hommerich. 2019. "No Generalizable Effect of Income Inequality on Public Support for Governmental Redistribution among Rich Democracies 1987-2010." Social Science Research 81(July):170-91. doi: 10.1016/j.ssresearch.2019.03.013.

Brooks, Clem and David Brady. 1999. "Income, Economic Voting, and Long-Term Political Change in the Us, 1952-1996." Social Forces 77(4):1339-74.

Carifio, James and Rocco J. Perla. 2007. "Ten Common Misunderstandings, Misconceptions, Persistent Myths and Urban Legends About Likert Scales and Likert Response Formats and Their Antidotes." Journal of Social Sciences 3(3):10616.

Castillo, Juan C. 2011. "Legitimacy of Inequality in a Highly Unequal Context." Social Justice Research 24(4):314-40.

Castles, Francis G. 2010. "The English-Speaking Countries." Pp. DOI: 10.1093/oxfordhb/9780199579396.003.0043 in The Oxford Handbook of the Welfare State, edited by F. G. Castles, S. Leibfried, J. Lewis, H. Obinger and C. Pierson. Oxford, England: Oxford Handbooks Online.

Centola, Damon. 2015. "The Social Origins of Networks and Diffusion." American Journal of Sociology 120,(5):1295-338. doi: 10.1086/681275.

Clifford, Scott, Ryan M Jewell and Philip D Waggoner. 2015. "Are Samples Drawn from Mechanical Turk Valid for Research on Political Ideology." Research \& Politics 2(4):doi:10.1177/2053168015622072.

Collins, Randall. 2019. "Emotional Micro Bases of Social Inequality." Emotions and Society 1(1):45-50. doi: https://doi.org/10.1332/263168919X15580836411823.

Crepaz, Markus M. L. . 2016. "Rumors That Diversity Is the Death of the Welfare State Are Greatly Exaggerated." Pp. 293-329 in Handbook on Immigration and Social Policy, edited by G. P. Freeman and N. Mirilovic. Cheltenham, UK: Edward Elgar.

Curtis, Josh. 2013. "Middle Class Identity in the Modern World: How Politics and Economics Matter." Canadian Review of Sociology 50(2):203-26.

D'Arms, Justin. 2017. "Envy." in The Stanford Encyclopedia of Philosophy (Spring 2017 Edition), (Ed.), Url =<Https:/Plato.Stanford.Edu/Archives/Spr2017/Entries/Envy/>. edited by E. N. Zalta. Palo Alto: Metaphysics Research Lab, Stanford University. $<$ https://plato.stanford.edu/archives/spr2017/entries/envy/>.

Day, Martin V. and Susan T. Fiske. 2016. "Movin' on Up? How Perceptions of Social Mobility Affect Our Willingness to Defend the System." Social Psychological and Personality Science 8(3):267-74. 
de la Mora, Gonzalo Fernandez 2000. Egalitarian Envy: The Political Foundations of Social Justice. Bloomington, IN: iUniverse.

Durkheim, Emile. 1961 [1893]. "On Mechanical and Organic Solidarity." Pp. 208-13 in Theories of Society, Volume 1, edited by T. Parsons, E. Shils, K. D. Naegele and J. R. Pitts. Glencoe, IL: Free Press.

Eriksson, Kimmo. 2018. "Republicans Value Agency, Democrats Value Communion." Social Psychology Quarterly 81(2):173-84. doi: 10.1177/0190272518771060.

Evans, M. D. R. and Jonathan Kelley. 2007. "Population Size, Economic Development, and Attitudes Towards Inequality: Evidence from 30 Nations." Population Review 46(2):1-23.

Evans, M.D.R., Jonathan Kelley and Tamas Kolosi. 1992. "Images of Class: Public Perceptions in Hungary and Australia." American Sociological Review 57(4):461-82.

Evans, M.D.R., Jonathan Kelley and Clayton Peoples. 2010. "Justifications of Inequality: The Normative Basis of Pay Differentials in 31 Nations." Social Science Quarterly 91(5):1405-31.

Evans, M.D.R. and Jonathan Kelley. 2018a. "Strong Welfare States Do Not Intensify Public Support for Income Redistribution, but Even Reduce It among the Prosperous: A Multilevel Analysis of Public Opinion in 30 Countries." Societies 8(4.105):1-52. Online. DOI: 10.3390/soc8040105. doi: 10.3390/soc8040105.

Evans, MDR and Jonathan Kelley. 2017. "Communism, Capitalism, and Images of Class: Effects of Reference Groups, Reality, and Regime in 43 Nations and 110,000 Individuals, 1987-2009." Cross-Cultural Research 51(4):315-59. doi: $10.1177 / 1069397116677963$.

Evans, MDR and Jonathan Kelley. 2018b. " Strong Welfare States Do Not Intensify Public Support for Income Redistribution, but Even Reduce It among the Prosperous: A Multilevel Analysis of

Public Opinion in 30 Countries: Section 2.1.8 Support for Redistribution. And Appendix C. Measurement of Redistributive Attitudes." Societies 8(4):Article 105. doi: https://doi.org/10.3390/soc8040105.

Feather, Norman. 1999. "Judgments of Deservingness: Studies in the Psychology of Justice and Achievement." Personality and Social Psychology Review, 3(1): 86-107. doi: 10.1207/s15327957pspr0302_1.

Feinstein, Yuval. 2020. " Applying Sociological Theories of Emotions to the Study of Mass Politics: The Rally-Round-the-Flag Phenomenon in the United States as a Test Case." The Sociological Quarterly 61(3):422-47. doi: 10.1080/00380253.2019.1711255.

Fernandez, Juan and Antonio M. Jaime-Castillo. 2018. "The Institutional Foundation of Social Class Differences in Pro-Redistribution Attitudes: A Cross-National 
Analysis, 1985-2010." Social Forces 96(3):1009-38. doi:

https://doi.org/10.1093/sf/sox068.

Fishbein, Morris and Icek Ajzen. 2010. Predicting and Changing Behavior: The Reasoned Action Approach. New York: Taylor \& Francis.

Foy, Steven, Reobert Freeland, Andrew Miles, Kimberly B. Rogers and Lynn SmithLovin. 2014. "Emotions and Affect as Source, Outcome, and Resistance to Inequality." Pp. 295-324 in Handbook of the Social Psychology of Inequality, edited by J. D. McLeod, E. J. Lawler and M. Schwalbe. Dordrecht, Netherlands: Springer.

Galland, Olivier, Yannick Lemel and Alexandr Frénod. 2013. "La Perception Des Inégalités En France." Revue européenne des sciences sociales 51(1):179 - 211.

Gerber, Alan S., Gregory A. Huber and Ebonya Washington. 2010. "Party Affiliation, Partisanship, and Political Beliefs." American Political Science Review 104(4):720-44.

Gijsberts, Merove. 2002. "The Legitimation of Income Inequality in State-Socialist and Market Societies." Acta Sociologica 45(4):269-85.

Hadler, Markus. 2005. "Why Do People Accept Different Income Ratios?: A Multi-Level Comparison of Thirty Countries." Acta Sociologica 48:131-54. doi: 10.1177/0001699305053768.

Hegtvedt, Karen A. and Christie L. Parris. 2014. "Emotions in Justice Processes." Pp. 103-26 in Handbook of the Sociology of Emotions: Volume Ii edited by J. E. Stets and J. H. Turner. Dordrecht, The Netherlands: Springer.

Heiserman, Nicholas and Brent Simpson. 2017. "Higher Inequality Increases the Gap in the Perceived Merit of the Rich and Poor." Social Psychology Quarterly 80(3):24353. doi: 10.1177/0190272517711919.

Heuer, Jan-Ocko, Steffen Mau and Katharina Zimmermann. 2018. "Attitudes to Inequalities: Citizen Deliberation About the (Re-)Distribution of Income and Wealth in Four Welfare State Regimes." in Attitudes, Aspirations and Welfare, edited by P. Taylor-Gooby and B. Leruth. Cham, Switzerland: Palgrave Macmillan.

Hitlin, Steven and Sarah K. Harkness. 2018. Unequal Foundations: Inequality, Morality, and Emotions across Cultures. New York: Oxford University Press.

Hofstede, Geert. 1984. Culture's Consequences: International Differences in Work-Related Values (2nd Ed.). Beverly Hills CA: SAGE Publications.

Ignacz, Szofia. 2018. "The Remains of the Socialist Legacy: The Influence of Socialist Socialization on Attitudes toward Income Inequality." Societies 8(3):doi:10.3390/soc8030062. doi: doi:10.3390/soc8030062.

Inglehart, Ronald. 2008. "Mapping Global Values." Comparative Sociology 5(2):115 - 36. Jaeger, Mads M. 2009. "United but Divided: Welfare Regimes and the Level and Variance in Public Support for Redistribution." European Sociological Review 25(6):723-37. doi: https://doi.org/10.1093/esr/jen079. 
Jasso, Guillermina and Peter H. Rossi. 1977. "Distributive Justice and Earned Income." American Sociological Review 42:639-51.

Jasso, Guillermina. 1980. "A New Theory of Distributive Justice." American Sociological Review 45(1):3-32.

Jasso, Guillermina. 2007. "Distributive Justice." Pp. 10.1002/9781405165518.wbeosd078 in The Blackwell Encyclopedia of Sociology, edited by G. Ritzer. Online: John Wiley \& Sons.

Jasso, Guillermina. 2008. "A New Unified Theory of Sociobehavioural Forces." European Sociological Review 24(4):411-34.

Jasso, Guillermina. 2015. "Thinking, Saying, Doing in the World of Distributive Justice." Social Justice Research 28:435-78.

Jennings, M Kent, Laura Stoker and Jake Bowers. 2009. "Politics across Generations." Journal of Politics 71(3):782-99.

Jo, Jung-In and Hyun Jin Choi. 2019. "Enigmas of Grievances About Inequality." International Area Studies Review Online before print:10.1177/2233865919833973.

Kelley, Jonathan and M.D.R. Evans. 1993. "The Legitimation of Inequality: Occupational Earnings in Nine Nations." American Journal of Sociology 99(1):75-125. doi: https://doi.org/10.1086/230230.

Kelley, Jonathan and M.D.R. Evans. 1995. "Class and Class Conflict in Six Western Nations." American Sociological Review 60(2):157-78.

Kelley, Jonathan and Krzysztof Zagorski. 2005. "Economic Change and the Legitimation of Inequality: The Transition from Socialism to the Free Market in Poland and Hungary, 1987-1994." Research in Social Stratification and Mobility 22:321-66.

Kelley, Jonathan and M.D.R. Evans. 2009. "Economic Development Reduces Tolerance for Inequality: A Comparative Analysis of 30 Nations." Pp. 49-72 in Charting the Globe: The International Social Survey Programme 1984-2009, edited by M. Haller, R. Jowell and T. Smith. London: Routledge.

Kelley, S. M. C. and C.G.E. Kelley. 2009. "Subjective Social Mobility: Data from 30

Nations." Pp. 106-24 in Charting the Globe, edited by M. Haller, R. Jowell and T. W. Smith. New York City: Routledge.

Kelly, Nathan J. and Peter K. Enns. 2010. "Inequality and the Dynamics of Public Opinion." American Journal of Political Science 54:855-70.

Kemp, Simon and Friedel Bolle. 2013. "Are Egalitarian Preferences Based on Envy?". The Journal of Socio-Economics 45(August): Pages 57-63. doi:

10.1016/j.socec.2013.04.006.

Kenworthy, Lane and Leslie McCall. 2008. "Inequality, Public Opinion and Redistribution." Socio-Economic Review 6(1):35-68. doi:

https://doi.org/10.1093/ser/mwm006.

Kierkegaard, Soeren. 1846. The Present Age (Trans. Alexander Dru). New York: Harper Torchbooks. 
Kocer, Ruya Gokhan and Herman G. van de Werfhorst. 2012. "Does Education Affect Opinions on Economic Inequality?". Acta Sociologica 55(3):251-72.

Kolczynska, Marta and Joseph J. Merry. 2016. "Preferred Levels of Income Inequality in a Period of Systemic Change: Analysis of Data from the Polish Panel Survey, Polpan 1988-2003." Polish Sociological Review 194(2):171-89.

Koos, Sebastian and Patrick Sachweh. 2017. "The Moral Economies of Market Societies: Popular Attitudes Towards Market Competition, Redistribution and Reciprocity in Comparative Perspective." Socio-Economic Review 17(4):793-821. doi: https://doi.org/10.1093/ser/mwx045.

Korupp, Sylvia E., Harry B.G. Ganzeboom and Tanja Van der Lippe. 2002. "Do Mothers Matter? A Comparison of Models of the Influence of Mother's and Father's Educational and Occupational Status on Children's Educational Attainment." Quality \& Quantity 36(1):17-42.

Kuhn, Andreas. 2015. "The Individual Perception of Wage Inequality: A Measurement Framework and Some Empirical Evidence." University of Zurich; IZA Institute of Labor Economics, Zurich, Switzerland.

Kulin, Joakim and Stefan Svallfors. 2013. "Class, Values, and Attitudes Towards Redistribution." European Sociological Review 29 (2):155-67. doi: https://doi.org/10.1093/esr/jcr046.

Laertius, Diogenes. 240BCE [1925]. "Book 7, Item 111." in Lives of the Philosophers: Life of Zeno of Citium, edited by R. D. Hicks. Athens, Greece: Aikaterini Laskaridi Foundation, now online at: https://topostext.org/work/221.

Larsen, Christian A. 2016. "How Three Narratives of Modernity Justify Economic Inequality." Acta Sociologica 59(2):93-111. doi: doi: 10.1177/000169931562280.

Li, Chen, Miron Zuckerman and Ed Diener. 2019. "Culture Moderates the Relation between Income Inequality and Subjective Well-Being." Journal Of Cross-cultural Psychology 50(10):1221-124. doi: https://doi.org/10.1177/0022022119883019.

Likert, Rensis. 1932. "A Technique for the Measurement of Attitudes." Archives of Psychology, Health \& Medicine 22(1):5-55. doi: (not available)

Lin, Ya-Feng, Yoshinori Kamo and Tim Slack. 2018. "Is It the Government's Responsibility to Reduce Income Inequality?". Sociological Spectrum 38(3):162-73. doi: 10.1080/02732173.2018.1469443.

Linos, Katerina and Martin West. 2003. "Self-Interest, Social Beliefs, and Attitudes Towards Redistribution." European Sociological Review 19(4):393-409.

Locke, E. A. 2007. "The Case for Inductive Theory Building." Journal of Management 33(6):867-90.

Macfarlane, Alan. 1978. The Origins of English Individualism. Oxford: Blackwell.

Manza, Jeff and Clem Brooks. 2012. "How Sociology Lost Public Opinion." Sociological Theory 30(2):89-113. doi: https://doi.org/10.1177/0735275112448054. 
Markus, Hazel R. 2017. "In This Together: Doing and Undoing Inequality and Social Class Divides." Journal of Social Issues 73(1):211-21. doi: 10.1111/josi.12212.

Mason, David S. 1995. "Justice, Socialism, and Participation in the Postcommunist States ." Pp. 56-63 in Social Justice and Political Change, edited by J. R. Kluegel, D. S. Mason and B. Wegener. New York: Aldine de Gruyter.

McCall, Leslie. 2003. "Do They Know and Do They Care? Americans' Awareness of Rising Inequality." Unpublished MS.

Meade, Adam W. and Gary J. Lautenschlager. 2004. "A Comparison of Item Response Theory and Confirmatory Factor Analytic Methodologies for Establishing Measurement Equivalence/Invariance." Organizational Research Methods 7(4):36188. doi: 10.1177/1094428104268027.

Merton, Robert K. and Elinor Barber. 2004. The Travels and Adventures of Serendipity. Princton, NJ: Princeton University Press.

Mettler, Suzanne and Mallory Sorelle. 2014. "Policy Feedback Theory." Pp. 151-82 in Theories of the Policy Process, edited by P. A. Sabatier and C. M. Weible. Boulder: Westview.

Mettler, Suzanne. 2018. The Government-Citizen Disconnect. New York, New York: Russell Sage.

Morgan, Stephen L. and Christopher Winship. 2014. Counterfacuals and Causal Inference. 2nd Edition. Cambridge: Cambridge University Press.

Mullinix, Kevin J. 2016. "Partisanship and Preference Formation." Political Behavior 38(2):383-411.

Niemi, Richard G. and M. Kent Jennings. 1991. "Issues and Inheritance in the Formation of Party Identification ". American Journal of Political Science 35(4 ):970-88.

Nietsche, Friedrich. 1887 [1967]. On the Geneology of Morals (Trans. Walter Kaufman, Part 1, Points 7-16). New York: Vintage.

Nowak, Piotr B. 2019. "Moment-Type Estimation from Grouped Samples." Statistics $\mathcal{E}$ Probability Letters 149(June):80-85. doi: 10.1016/j.spl.2019.01.010.

O'Brien, Robert M. and Pamela Homer. 1987. "Corrections for Coarsely Categorized Measures." Quality \& Quantity 21(4):349-60.

Osberg, Lars and Timothy Smeeding. 2006. "“Fair" Inequality? Attitudes toward Pay Differentials." American Sociological Review 71 issue(3):450-73. doi: https://doi.org/10.1177/000312240607100305.

Papadakis, Elim and Clive S. Bean. 1993. "Popular Support for the Welfare State." Journal of Public Policy 13(3):227-54. doi: https://doi.org/10.1017/S0143814X00001057.

Pettigrew, Thomas F. and Miles Hewstone. 2017 "The Single Factor Fallacy: Implications of Missing Critical Variables from an Analysis of Intergroup Contact Theory." Social Issues and Policy Review 11(1):8-37. 
Rawls, John. 1971. A Theory of Justice. Cambridge, MA: Harvard University Press.

Ritzman, Rosemary L. and Donald Tomaskovic-Devey. 1992. "Life Chances and Support for Equality and Equity as Normative and Counternormative Distribution Rules." Social Forces 70(3):745-63. doi: 10.1093/sf/70.3.745.

Rodriguez-Bailon, Rosa, Boyka Bratanova, Guillermo B. Willis, Lucia Lopez-Rodriguez, Ashley Sturrock and Steve Loughnan. 2017. "Social Class and Ideologies of Inequality: How They Uphold Unequal Societies." Journal of Social Issues 73(1):99_ 116. doi: 10.1111/josi.12206.

Roex, Karlijn L.A., Tim Huijts and Inge Sieben. 2018. "Attitudes Towards Income Inequality: 'Winners' Versus 'Losers' of the Perceived Meritocracy." Acta Sociologica 62(1):47-63. doi: https://doi.org/10.1177/0001699317748340.

Roex, Karlijn L.A., Tim Huijts and Inge Sieben. 2019. "Attitudes Towards Income Inequality." Acta Sociologica 62(1):47-63. doi: 10.1177/0001699317748340.

Rozer, Jesper and Gerbert Kraaykamp. 2013. "Income Inequality and Subjective WellBeing: A Cross-National Study on the Conditional Effects of Individual and National Characteristics." Social Indicators Research 113(3):1009-23. doi: 10.1007/s11205-012-0124-7.

Sachweh, Patrick. 2012. "The Moral Economy of Inequality: Popular Views on Income Differentiation, Poverty and Wealth." Socio-Economic Review 10 (3):419-45. doi: https://doi.org/10.1093/ser/mwr023.

Scheler, Max. 1914 [1994]. "On the Phenomenology and Sociology of Ressentiment " Pp. Chapter 2 in Ressentiment (T Ransl.William W. Holdheim). Milwaukee, WI: Marquette University Press.

Schmidt-Catran, Alexander W. 2016. "Economic Inequality and Public Demand for Redistribution: Combining Cross-Sectional and Longitudinal Evidence." SocioEconomic Review 14(1):119-40. doi: 10.1093/ser/mwu030.

Schoeck, Helmut. 1987[1966]. Envy: A Theory of Social Behaviour. Carmel, IN: Liberty Fund Inc.

Shamon, Hawal and Hermann Duelmer. 2014. "Raising the Question on 'Who Should Get What?' Again: The Importance of Ideal and Existential Standards.". Social Justice Research 27(3):340-68.

Sikora, Joanna. 2005. "Perceptions of Economic Efficiency of Government Versus Private Enterprises, and Attitudes to Government Ownership in the Economy." Research in Social Stratification and Mobility 23:227-74.

Simkus, Albert and Peter Robert. 1995. "Attitudes toward Inequality: Cross-National Comparisons and Class Divisions in Hungary." International Journal of Sociology 25(4):85-102.

Sirkin, R. Mark. 2006. "The Standardized Partial Regression Slope." Pp. 528-30 in Statistics for the Social Sciences. Thousand Oaks, CA: Sage. 
Smith, Michael L. and Petr Mateju. 2012. "Two Decades of Value Change: The Crystallization of Meritocratic and Egalitarian Beliefs in the Czech Republic." Social Justice Research 25(4):421-39.

Smith, Richard H., W. Gerrod Parrott, Edward F. Diener, Rick H. Hoyle and Sung Hee Kim. 1999. "Dispositional Envy." Personality and Social Psychology Bulletin 25 (8):1007-20. doi: 10.1177/01461672992511008.

Springer, Victoria A., I. Stephanie Vezich, Samuel C. Lindsey and Peter J. Martini. 2016. "Practice-Based Considerations for Using Multi-Stage Survey Design to Reach Special Populations on Amazon's Mechanical Turk." Survey Practice 9(5):1-10.

Stark, Stephen, Oleksandr S. Chernyshenko and Fritz Drasgow. 2006. "Detecting Differential Item Functioning with Confirmatory Factor Analysis and Item Response Theory." Journal of Applied Psychology 91(6):1292-306. doi: 10.1037/00219010.91.6.1292.

Steele, Liza G. 2015. "Income Inequality, Equal Opportunity, and Attitudes About Redistribution." Social Science Quarterly 96(2):444-64.

Sznycer, Daniel, Maria Florencia Lopez Seal, Aaron Sell, Julian Lim, Roni Porat, Shaul Shalvi, Eran Halperin, Leda Cosmides and John Tooby. 2017. "Support for Redistribution Is Shaped by Compassion, Envy, and Self-Interest, but Not a Taste for Fairness." PNAS (Proceedings of the National Academy of Sciences) 114(31):842025. doi: 10.1073/pnas.1703801114.

Tay, Louis, Adam W. Meade and Mengyang Cao. 2014. "An Overview and Practical Guide to Irt Measurement Equivalence Analysis." Organizational Research Methods 18(1):3-46. doi: 10.1177/1094428114553062.

Treiman, Donald J. 2009. "Standardized Coefficients." Pp. 107-10 in Quantitative Data Analysis. San Francisco, CA: Jossey-Bass.

Turner, Jonathan H. 2007. "Justice and Emotions." Social Justice Research 20(3):288-311. doi: 10.1007/s11211-007-0043-y.

Ven, Niels van de and Marcel Zeelenberg. 2019. "Envy and Social Comparison." in Social Comparison, Judgment and Behavior, edited by J. Suls, R. Collins and L. Wheeler. Oxford, England: Oxford University Press.

Vittinghoff, Eric, David V. Glidden, Stephen C. Shiboski and Charles E. McCulloch. 2005. "Standardized Regression Coefficients." Pp. 75-76 in Regression Methods in Biostatistics: Linear, Logistic, Survival, and Repeated Measures Models. Berlin, Germany: Springer.

Warne, Russell T. 2017. "Regression." Pp. 369-402 in Statistics for the Social Sciences. Cambridge, England: Cambridge University Press.

Weakliem, David L., Robert Andersen and Anthony F. Heath. 2005. "By Popular Demand: The Effect of Public Opinion on Income Inequality." Comparative Sociology 4:261-84. 
Weinberg, Jill D., Jeremy Freese and David McElhattan. 2014. "Comparing Data Characteristics and Results of an Online Factorial Survey between a PopulationBased and a Crowdsource-Recruited Sample." Sociological Science 1(1):292-310.

Zagorski, Krzysztof. 1996. "Transformation, Reforms and Attitudes to Neo-Corporatism in Poland, Finland and Australia." in Values and Radical Social Change, edited by E. Wnuk-Lipinski. Warsaw: ISP PAN.

Zagorski, Krzysztof. 1999. "Egalitarianism, Perception of Conflicts and Support for Transformation." Ch. 9 in The End of the Welfare State?, edited by S. Svallfors and P. Taylor-Gooby. London: Routledge. 